\title{
LAND USE IN SELECTED EROSION-RISK AREAS OF TERTIARY LOW HILLS IN SLOVENIA
}

\section{RABA TAL NA IZBRANIH EROZIJSKO OGROZENIH OBMOCJIH TERCIARNIH GRICEVIJ V SLOVENIJI}

Mauro Hrvatin, Drago Perko, Franci Petek

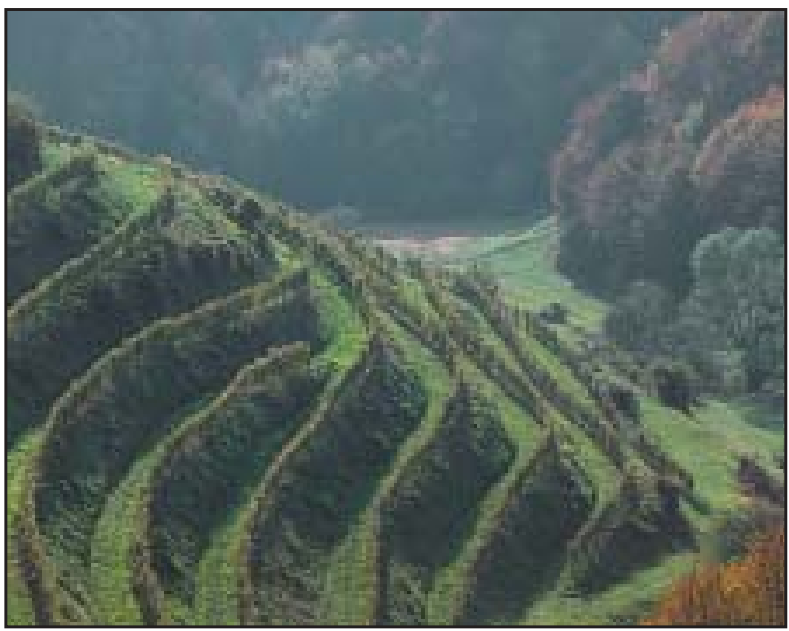

Most vineyards in Haloze are located on steep and unstable slopes (photograph: Igor Maher).

Večina vinogradov v Halozah je na strmih in nestabilnih pobočjih (fotografija: Igor Maher).

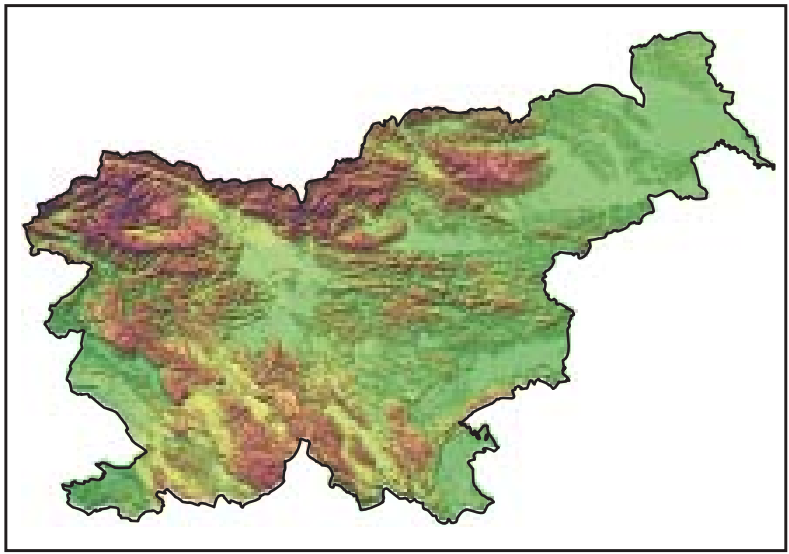




\section{Land use in selected erosion-risk areas of Tertiary low hills in Slovenia}

UDC: 551.43:711.14(497.4)

COBISS: 1.01

ABSTRACT: In this article we determine the potential erosion risk of sites with respect to surface morphology and how it is related to the distribution of individual types of land use. We investigated the relationship between relief factors affecting erosion risk (elevation, slope, and aspect of the surface) and types of land use (arable land, vineyards, orchards, grassland, woodland, and built-up and other areas) in six $24 \mathrm{~km}^{2}$ sectors in Tertiary low hill areas in Slovenia: Koprska brda, Brkini, Goriška brda, Haloze, Slovenske gorice and Goričko. The areas selected are of particular interest due to the prevalence of rock substrates which are susceptible to erosion. The potential erosion risk was determined by the stream power index. In the Haloze sector, land use was most closely correlated with the aspect of the surface, in Slovenske gorice sector with the surface height, and in the remaining sectors with the potential erosion risk.

KEY WORDS: land use, relief, surface, digital elevation model, height, slope, aspect, erosion, Slovenia.

The article was submitted for publication on May 18, 2006.

ADDRESSES:

Mauro Hrvatin, B. Sc.

Anton Melik Geographical Institute

Scientific Research Centre of the Slovenian Academy of Sciences and Arts

Gosposka ulica 13, SI - 1000 Ljubljana, Slovenia

E-mail:mauro@zrc-sazu.si

Drago Perko, Ph. D.

Anton Melik Geographical Institute

Scientific Research Centre of the Slovenian Academy of Sciences and Arts

Gosposka ulica 13, SI - 1000 Ljubljana, Slovenia

E-mail: drago@zrc-sazu.si

Franci Petek, Ph. D.

Anton Melik Geographical Institute

Scientific Research Centre of the Slovenian Academy of Sciences and Arts

Gosposka ulica 13, SI - 1000 Ljubljana, Slovenia

E-mail: petek@zrc-sazu.si

\section{Contents}

1 Introduction $\quad 59$

2 Selected areas $\quad 61$

3 Land use $\quad 66$

4 Elevation $\quad 69$

5 Slope $\quad 71$

6 Aspect 72

$7 \quad$ Potential erosion risk 74

8 Conclusion $\quad 76$

9 References $\quad 77$ 


\section{Introduction}

Relief or surface morphology is the landscape element that contributes most to the external appearance of Slovene landscapes, while land use, which is strongly dependent on the natural and social elements of the landscape, is one of the most important as well as most visible indicators of the natural and social conditions in the landscape. In some places land use is related to and in keeping with the relief, while in other places it is not.

In this article we analyze the relief indicators, or indicators of surface morphology and potential erosion risk, with respect to various types of land use, and identify the differences among them. On this basis we determine the degree to which relief indicators and types of land use are related, or in other words the influence of relief on land use, and particularly the extent to which the land use is in keeping with the potential erosion risk of the land surface.

In 2000 researchers at the Scientific Research Institute of the Slovene Academy of Arts and Sciences performed an analysis of radar photos taken by the European Space Agency from 1995 to 1999 . We developed a twenty-five-meter digital elevation model, a so-called Interferometric Synthetic Aperture Radar Digital Elevation Model, or InSAR DEM 25, for the Surveying and Mapping Authority of the Republic of Slovenia (Podobnikar, Oštir 1999; Oštir, Podobnikar, Stančič, Mlinar 2000; Podobnikar 2002). It is composed of elevation data points taken from north to south at 25-meter intervals, which form the corners of square cells with a side measuring $25 \mathrm{~m}$, a diagonal of $35 \mathrm{~m}$ and an area of $625 \mathrm{~m}^{2}$.

By taking into account a more extensive collection of relief data from the 1990s, we condensed the DEM 25 into a DEM 12.5 between 2003 and 2005 (Podobnikar 2005). It is composed of elevation data points from north to south at 12.5-meter intervals, which form the corners of square cells with a side of $12.5 \mathrm{~m}$, diagonal of $17.7 \mathrm{~m}$ and area of $156.25 \mathrm{~m}^{2}$.

Testing showed that the accuracy of the DEM 12.5 for Slovenia as a whole is within $3.2 \mathrm{~m}: 1.1 \mathrm{~m}$ in level areas, $2.3 \mathrm{~m}$ in areas of low hills, $3.8 \mathrm{~m}$ in hilly areas, and 7.0 $\mathrm{m}$ in mountain areas (Podobnikar 2006, 25).

From three basic geometrical properties of a plane which we can determine with a digital elevation model using geographical information systems - distance, inclination, and curvature with respect to the horizontal and vertical planes (Perko 2002; Hrvatin in Perko 2002; Hrvatin in Perko 2003) - for the purposes of comparison we selected three properties or indicators which are most often used in geography. These are:

- height of the land surface, i. e. distance of the surface with respect to the horizontal plane,

- slope of the surface, i. e. inclination of the surface with respect to the horizontal plane, and

- aspect of the surface, i. e. inclination of the surface with respect to the vertical plane.

The indicators obtained in the DEM 12.5 are based on 153,600 data points for each region (Figure 1), which were labeled according to the name of the settlement central to the sector selected.

Height is provided in meters, slope in degrees, from 0 for a horizontal surface to 90 for a vertical one, and aspect in degrees, from 0 for an extreme northerly position to 180 for an extreme southerly position. We calculated these values for six sectors from areas of Tertiary low hills in Slovenia, which are of particular interest due to the prevalence of rock substrates which are susceptible to erosion. We selected Koprska brda, Brkini and Goriška brda from among Mediterranean low hill areas, and Haloze, Slovenske gorice and Goričko from among inland low hill areas. All the sectors were rectangular in shape and had a length of $6 \mathrm{~km}$, a width of $4 \mathrm{~km}$ and an area of $24 \mathrm{~km}^{2}$. We used the IDRISI (Eastman 1995) and ArcGIS (Shaner, Wrightsell 2000; Tucker 2000; McCoy, Johnston 2001) software packages for calculating the indicators of relief and for integrating data on relief, rock substrates, and river systems and watersheds.

As the fourth indicator of relief we added the potential erosion risk of the surface, as determined by the stream power index (Lindsay 2005; Komac, Zorn 2005).

The stream power index is a measure of the denudation and erosion potential of water and is based on the assumption that the water stream and the denudation-erosion capacity of water increase proportionally with an increase in the specific catchment area. The index takes into account the area of the upslope contributing area, the unit contour length and the slope of the upslope contributing area. In using the digital elevation model the area of the upslope contributing area was equal to the area of the upslope contributing area of the rectangular cell, the unit contour length was equal to the length of the rectangular cell, and the slope of the surface along the unit contour was equal to the slope of the rectangular cell or rather the slope of the group of rectangular cells. 


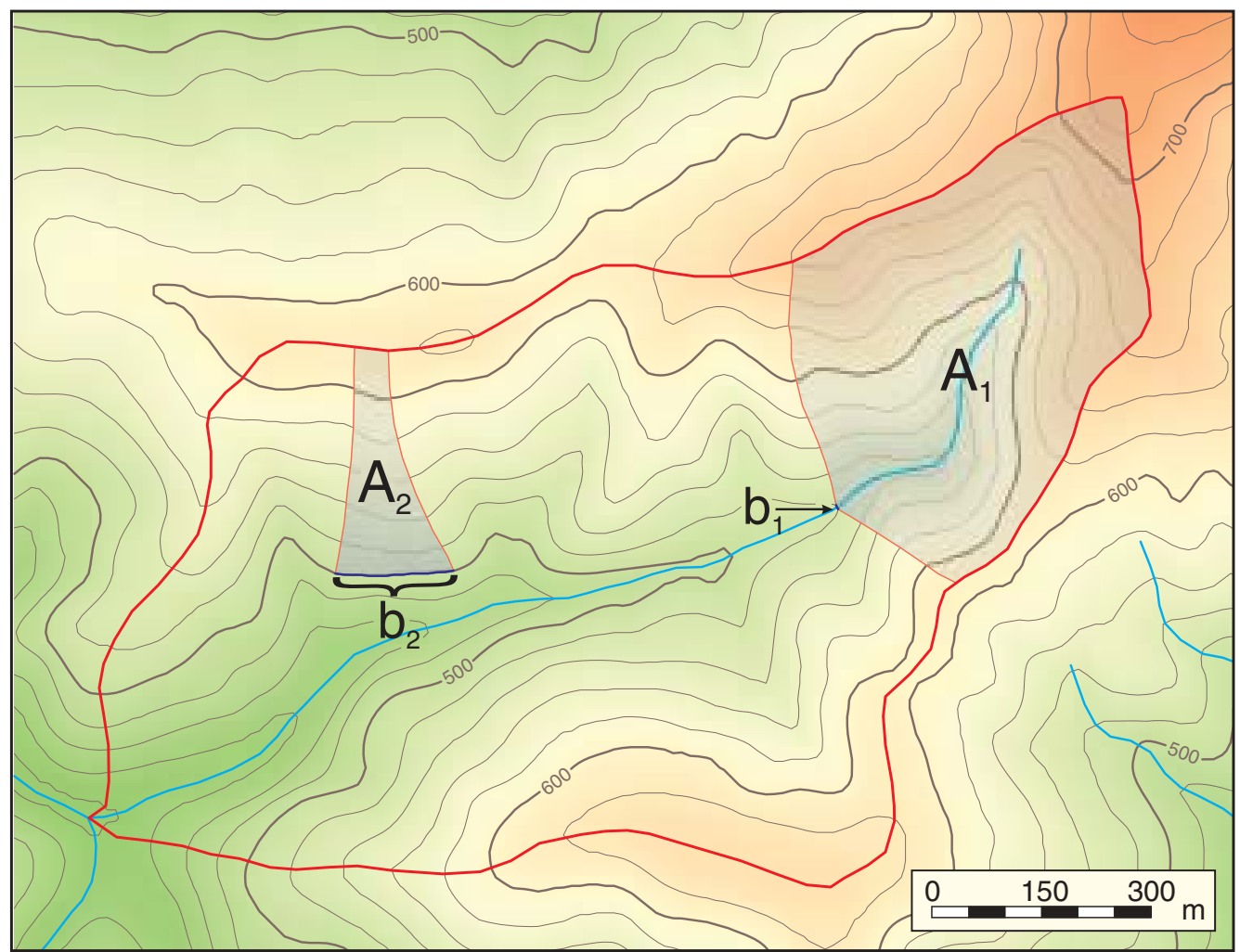

Figure 1: The sketch of the calculation of the stream power index shows two cases in the catchment area of Suhi potok in the hills along the Sava River area (catchment area outlined in red), in which A is the area of the upslope contributing area, $b$ is the contour unit length, and $\alpha$ is the slope of the surface along the unit contour. The stream power index $I_{\text {MVT }}=(A: b) \cdot \tan \alpha$. In the first instance the stream power index is $\left.2143 \mathrm{~m}^{2} / \mathrm{m}\left(I_{M V T}=\left(245,000 \mathrm{~m}^{2}: 10 \mathrm{~m}\right) \cdot \tan 5^{\circ}\right)\right)$, and in the second instance it is $\left.94 \mathrm{~m}^{2} / \mathrm{m}\left(I_{M V T}=\left(29,580 \mathrm{~m}^{2}: 160 \mathrm{~m}\right) \cdot \tan 27^{\circ}\right)\right)$.

The lowest value of the stream power index, when the surface of the unit contour or the rectangular cell is flat, is 0 . In this case the potential erosion risk is also 0 . The greater the value of the index, the greater the potential erosion risk.

For the purposes of our investigation we divided the indexes into four categories and labeled them as follows:

- negligible erosion (index between 0 and 9),

- weak erosion (index between 10 and 99),

- moderate erosion (index between 100 and 999),

- strong erosion (index of 1000 and higher).

The relationship between surface morphology and potential erosion risk and land use was determined:

- descriptively by means of the distribution of individual types of land use according to classes of height, slope, and aspect of the surface, and the potential erosion risk;

- mathematically by means of Hirschman's concentration coefficient $c c$ (Blejec 1976, Perko 2001), which is based on the proportion of individual types of land use according to classes of a specific relief indicator, and has values between 0 where a specific type of land use is evenly distributed over all classes and 1 where it is focused or concentrated in only one class (the higher the concentration coefficient, the greater the density of the individual type of land use and the greater the possibility that this density is not accidental but dependent on a particular relief indicator),

- mathematically by means of the contingency correlation coefficient $\boldsymbol{r}$ (Blejec 1976, Perko 2001), which is based on $h i^{2}$ or the frequency of occurrence of all types of land use in all classes of the contingency table of a specific relief indicator. 
All the calculated values of $h i^{2}$ and the correlation coefficient significantly exceed the value of the threshold $h i^{2}$ and the threshold correlation coefficient for statistical significance with $99.9 \%$ confidence, which means that we can conclude that the height, slope, aspect, and potential erosion risk of a surface are related to types of land use in a statistically significant way.

\section{Selected regions}

We selected six regions of Tertiary low hills: Koprska brda, Brkini and Goriška brda from among Mediterranean low hill areas, and Haloze, Slovenske gorice and Goričko from among inland low hill areas (Figure 2).

In the Koprska brda region (Figure 3) we chose a sector in the southeastern part near the settlement of Bočaji, on rolling flysch hills in the upper catchment area of the Dragonja River with a change in height from 82 to $415 \mathrm{~m}$, an average slope of $13.2^{\circ}$, an average aspect of $99.9^{\circ}$ and an average stream power index of $70.8 \mathrm{~m}^{2} / \mathrm{m}$. The area is characterized by scattered nucleated settlements, of which only Marezige is of any size.

In the Brkini region (Figure 4) we chose a sector on a central flysch slope near the settlement of Pregarje with a change in elevation from 437 to $771 \mathrm{~m}$, an average slope of $16.2^{\circ}$, an average aspect of $94,1^{\circ}$, and an average stream power index of $64.6 \mathrm{~m}^{2} / \mathrm{m}$. Typical of the area are scattered small compact settlements which in some places are spread out along the slopes.

In the Goriška brda region (Figure 5) we chose a sector in the central flysch area near the settlement of Imenje with a change in height from 77 to $426 \mathrm{~m}$, an average slope of $16.5^{\circ}$, an average aspect of $99.0^{\circ}$ and an average stream power index of $66.6 \mathrm{~m}^{2} / \mathrm{m}$. Typical of this area are numerous nucleated settlements, the larger among them being Dobrovo, Kozana, Kojsko, Hum and Šmartno.

In the western forested part of the Haloze region (Figure 6) we chose a sector in the central marl area around the settlement of Kočice with a change in elevation from 253 to $512 \mathrm{~m}$, an average slope of $21.7^{\circ}$, an average aspect of $92.3^{\circ}$ and an average stream power index of $59.3 \mathrm{~m}^{2} / \mathrm{m}$. Typical of the area are infrequent dispersed settlements consisting of numerous hamlets scattered over a wide area.

Table 1: Some statistical indicators for surface height, surface slope and surface aspect for the selected areas.

\begin{tabular}{|c|c|c|c|c|c|c|}
\hline & $\begin{array}{c}\text { Bočaji } \\
\text { (Koprska brda) }\end{array}$ & $\begin{array}{l}\text { Pregarje } \\
\text { (Brkini) }\end{array}$ & $\begin{array}{c}\text { Imenje } \\
\text { (Goriška brda) }\end{array}$ & $\begin{array}{c}\text { Kočice } \\
\text { (Haloze) }\end{array}$ & $\begin{array}{c}\text { Pršetinci } \\
\text { (Slovenske gorice) }\end{array}$ & $\begin{array}{l}\text { Markovci } \\
\text { (Goričko) }\end{array}$ \\
\hline \multicolumn{7}{|l|}{ height } \\
\hline minimum & 82.0 & 437.0 & 77.0 & 253.0 & 213.0 & 246.0 \\
\hline maximum & 415.0 & 771.0 & 426.0 & 512.0 & 326.0 & 352.0 \\
\hline range & 333.0 & 334.0 & 349.0 & 259.0 & 113.0 & 106.0 \\
\hline average & 272.8 & 603.1 & 186.0 & 348.1 & 264.9 & 297.8 \\
\hline standard deviation & 56.9 & 70.5 & 73.0 & 42.6 & 21.1 & 21.8 \\
\hline \multicolumn{7}{|l|}{ slope } \\
\hline minimum & 0.0 & 0.0 & 0.0 & 0.0 & 0.0 & 0.0 \\
\hline maximum & 45.0 & 43.9 & 47.7 & 54.0 & 31.9 & 24.5 \\
\hline range & 45.0 & 43.9 & 47.7 & 54.0 & 31.9 & 24.5 \\
\hline average & 13.2 & 16.2 & 16.5 & 21.7 & 8.2 & 6.6 \\
\hline standard deviation & 6.9 & 7.2 & 8.0 & 9.5 & 5.0 & 3.6 \\
\hline \multicolumn{7}{|l|}{ aspect } \\
\hline minimum & 0.0 & 0.0 & 0.0 & 0.0 & 0.0 & 0.0 \\
\hline maximum & 180.0 & 180.0 & 180.0 & 180.0 & 180.0 & 180.0 \\
\hline range & 180.0 & 180.0 & 180.0 & 180.0 & 180.0 & 180.0 \\
\hline average & 99.9 & 94.1 & 99.0 & 92.3 & 96.4 & 105.2 \\
\hline standard deviation & 57.5 & 50.3 & 51.6 & 51.8 & 53.8 & 50.8 \\
\hline \multicolumn{7}{|c|}{ relative stream power index } \\
\hline minimum & 0.0 & 0.0 & 0.0 & 0.0 & 0.0 & 0.0 \\
\hline maximum & 10979 & 7975 & 7253 & 5636 & 890 & 1119 \\
\hline range & 10979 & 7975 & 7253 & 5636 & 890 & 1119 \\
\hline average & 70.8 & 64.6 & 66.6 & 59.3 & 22.3 & 18.7 \\
\hline standard deviation & 189.3 & 141.3 & 169.0 & 103.6 & 35.2 & 26.3 \\
\hline
\end{tabular}




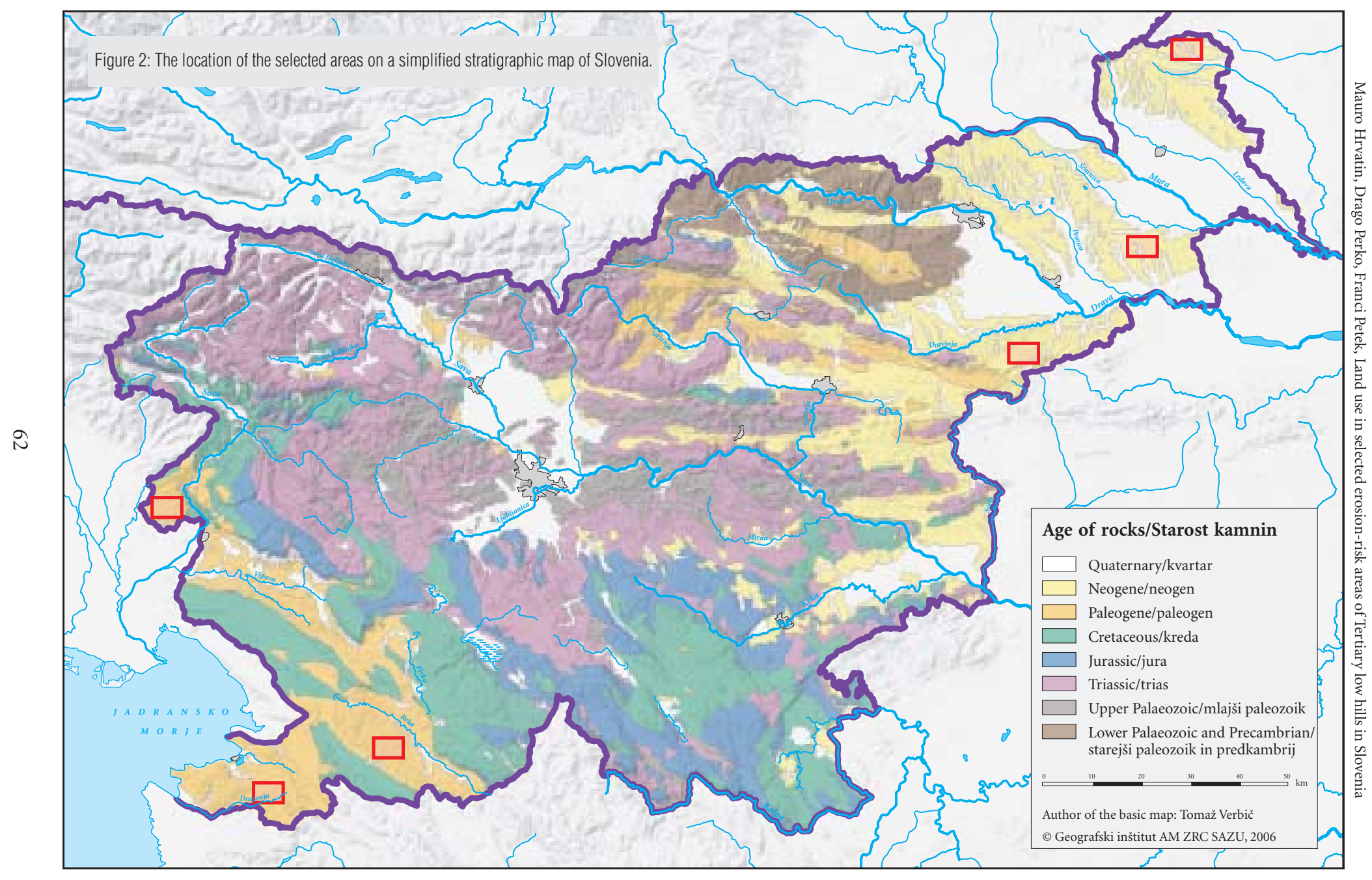




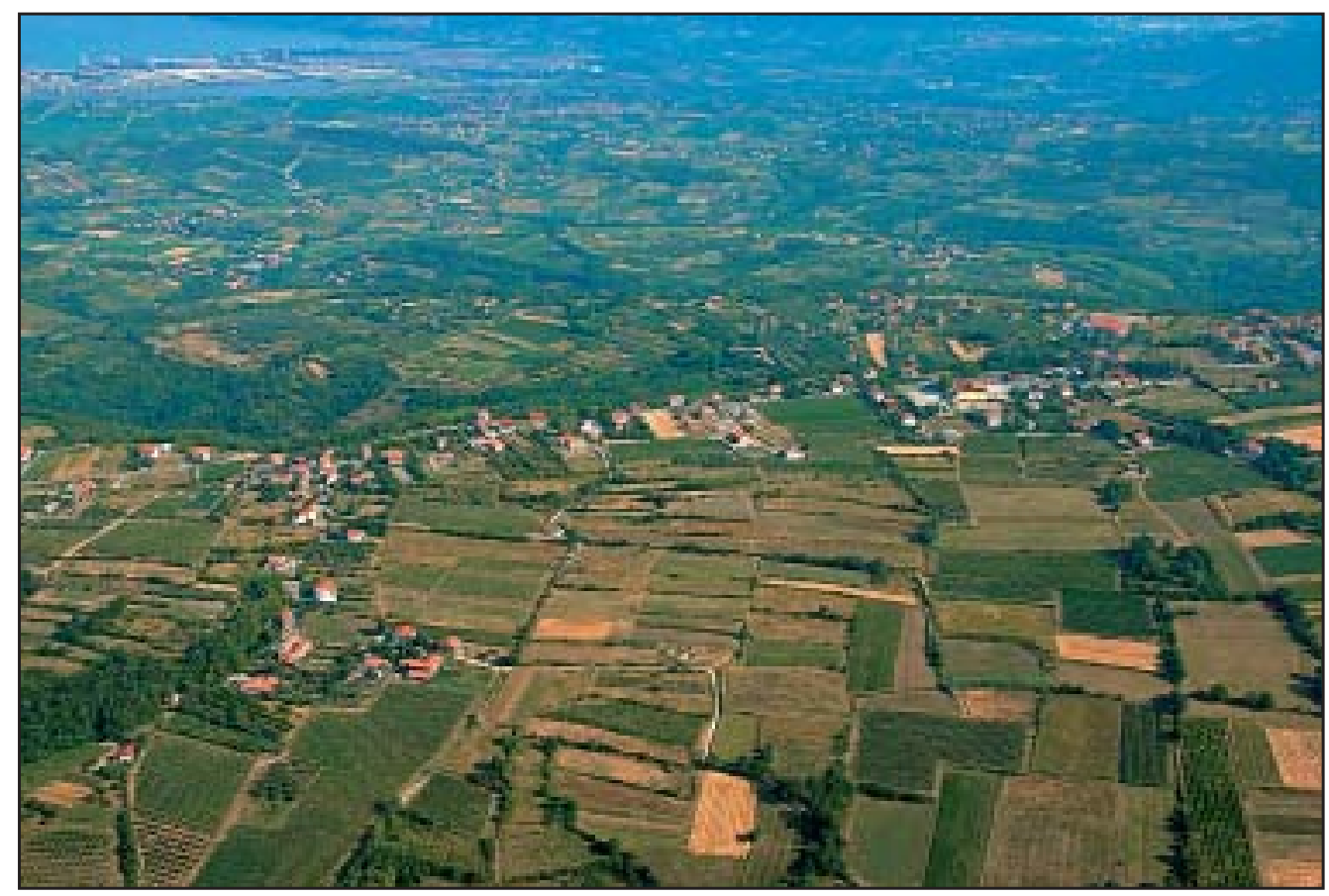

Figure 3: The area around Bočaji, in the Koprska brda region (photograph: Matevž Lenarčič).

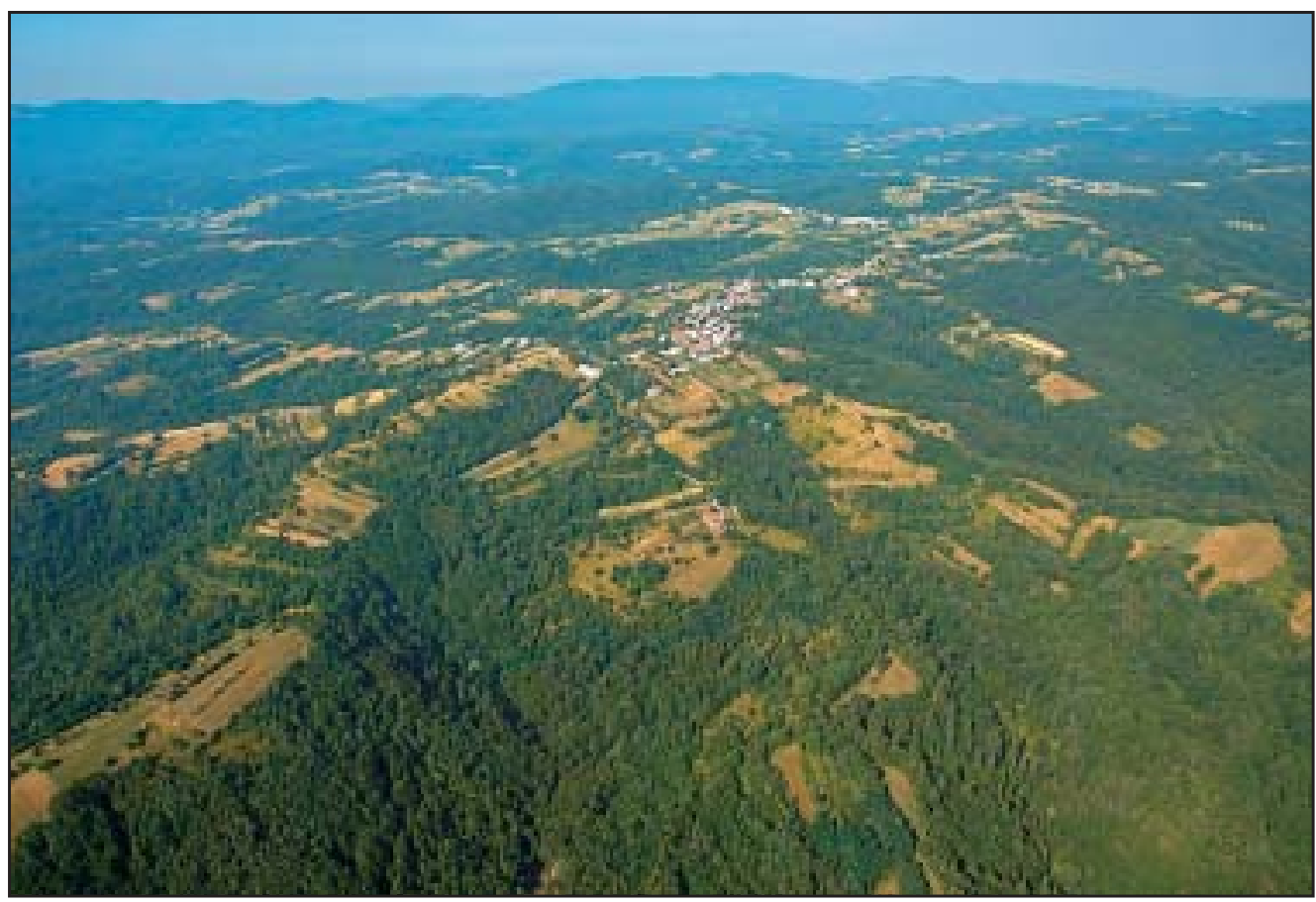

Figure 4: The area around Pregarje, in the Brkini region (photograph: Matevž Lenarčič). 


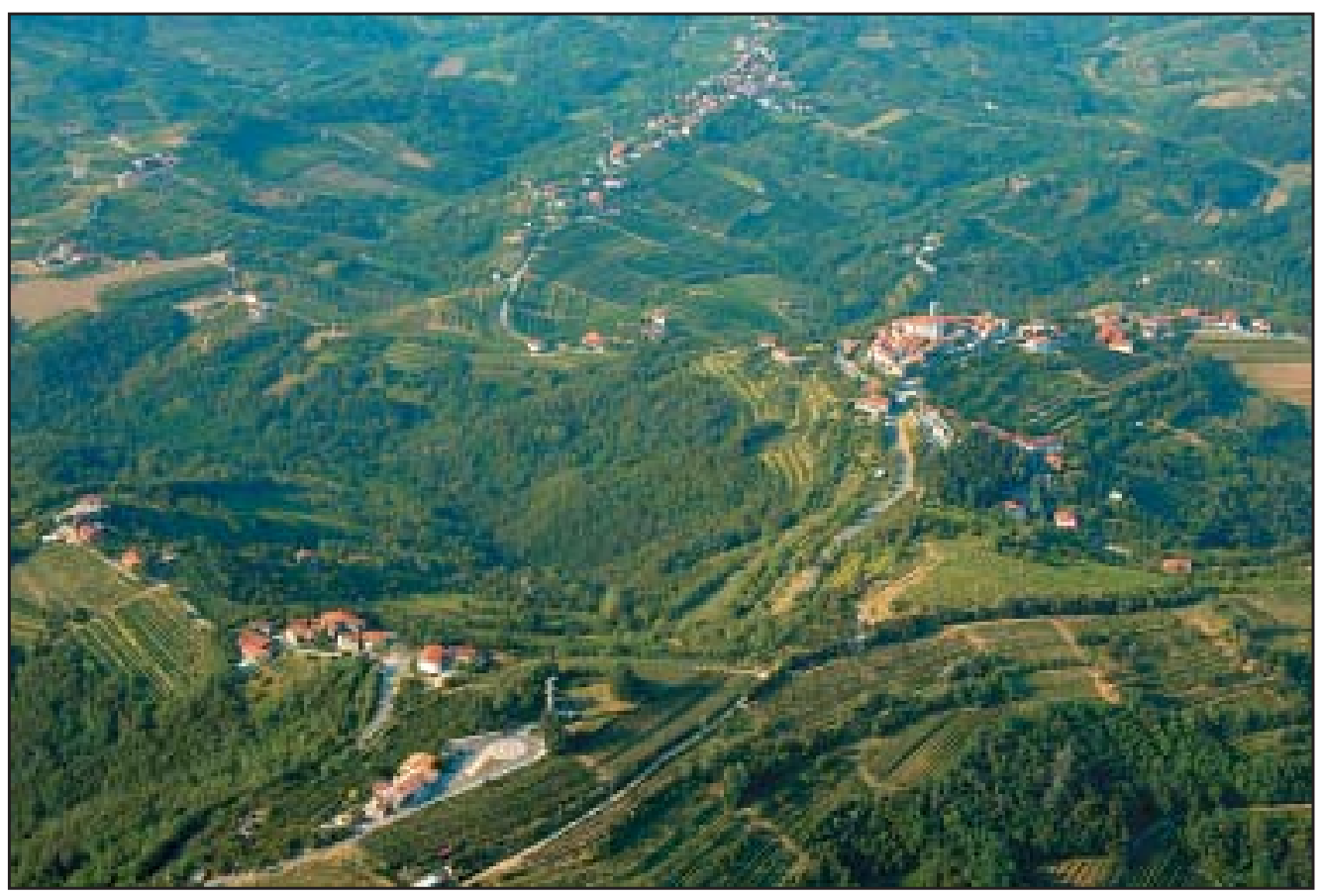

Figure 5: The area around Imenje, in the Goriška brda region (photograph: Matevž Lenarčič).

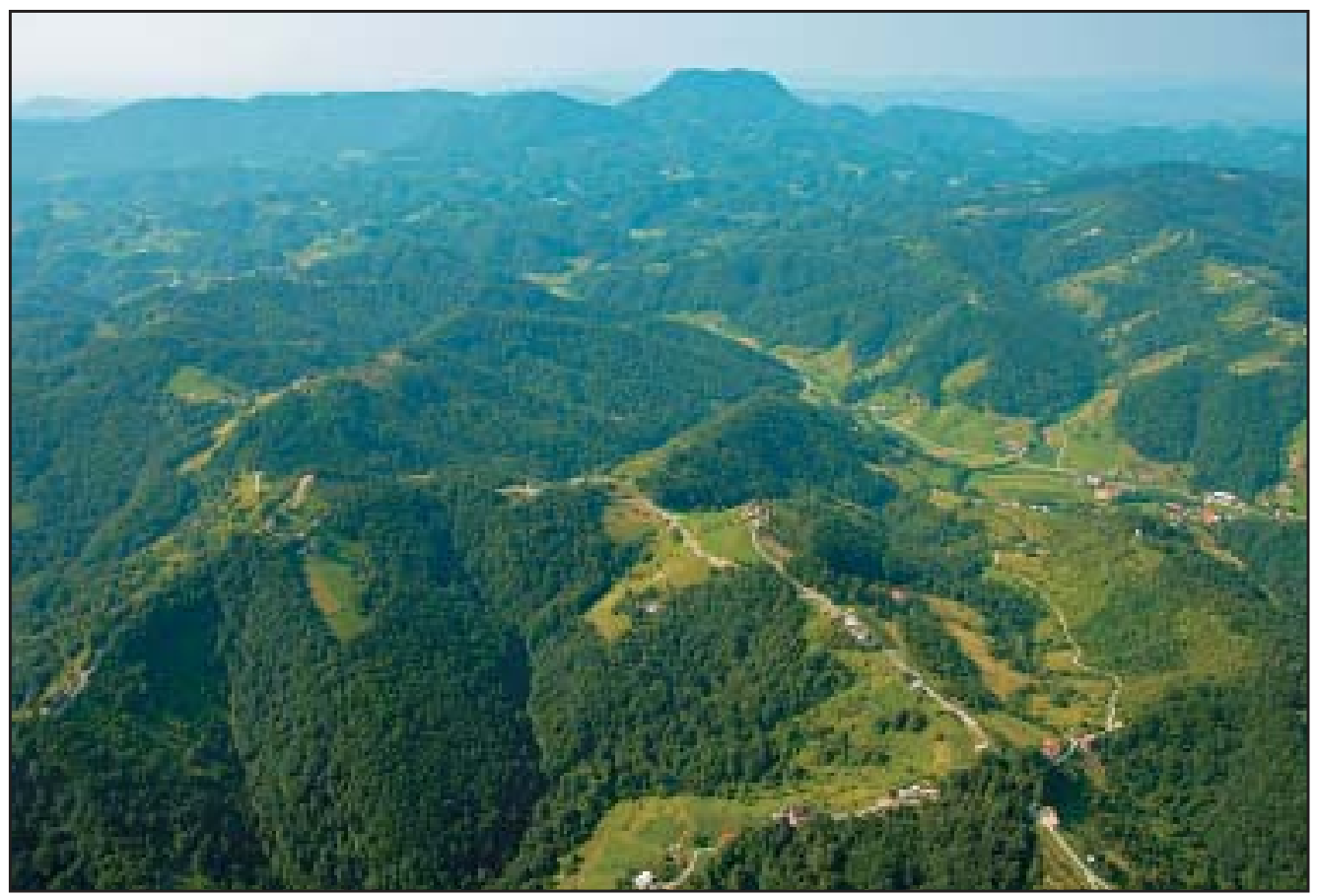

Figure 6: The area around Kočice, in the Haloze region (photograph: Matevž Lenarčič). 


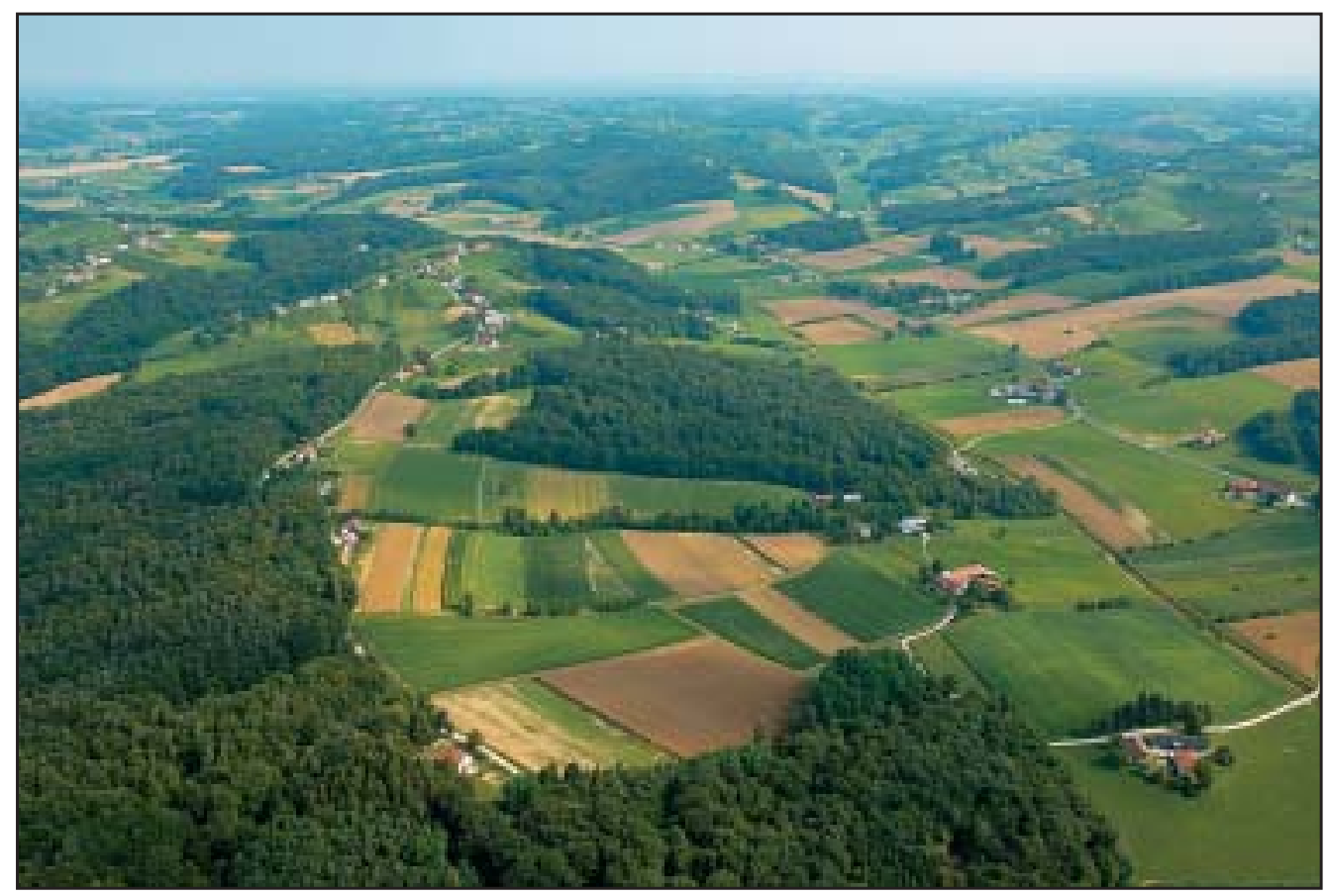

Figure 7: The area around Pršetinci, in the Slovenske gorice region (photograph: Matevž Lenarčič).

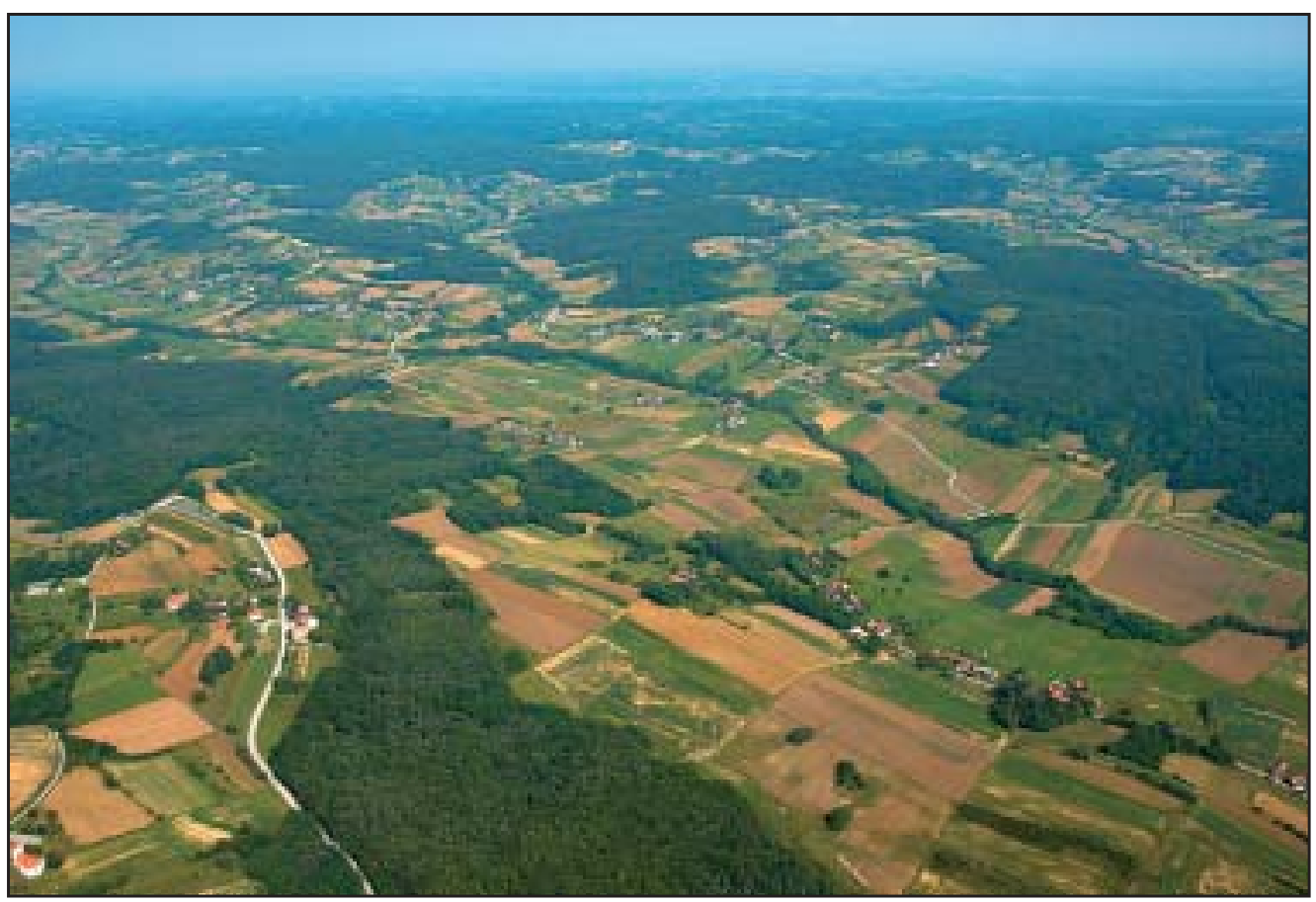

Figure 8: The area around Markovci, in the Goričko region (photograph: Matevž Lenarčič). 
In the Slovenske gorice region (Figure 7) we chose a sector on sandy and gravelly land around the settlement of Pršetinci with a change in height from 213 to $326 \mathrm{~m}$, an average slope of $8.2^{\circ}$, an average aspect of $96.4^{\circ}$ and an average stream power index of $22.3 \mathrm{~m}^{2} / \mathrm{m}$. A dense network of relatively small settlements with a dispersed layout typifies this area.

In the Goričko region (Figure 8) we chose a sector on clay and gravel land around the settlement of Markovci with a change in height from 246 to $352 \mathrm{~m}$, an average slope of $6.6^{\circ}$, an average aspect of $105.2^{\circ}$ and an average stream power index of $18.7 \mathrm{~m}^{2} / \mathrm{m}$. Settlements in this area are typically infrequent and dispersed in layout.

\section{Land use}

The term »land use « primarily refers to the allocation of the surface or land in a region for economic or other activities. The branches of geography in Slovenia which are most involved in the study of land use are agricultural geography (Gabrovec and Kladnik 1997, Kladnik and Gabrovec 1998, Gabrovec, Kladnik and Petek 2001, Petek 2002) and rural geography (Urbanc 2002, Kladnik and Ravbar 2003, Topole 2003).

Areas or land with the same land use are referred to as »land categories « or »types of land use." The basic source for studying land use is data from the land register maintained in Slovenia by the Surveying and Mapping Authority of the Republic of Slovenia for cadastral municipalities. The 2698 cadastral municipalities in Slovenia are the basic territorial units of the land register. Due to delays in updating changes, the data in the register frequently lag behind the actual conditions for the land.

The oldest official land register in the territory of today's Slovenia is the Franciscan cadastre from the first half of the 19th century. It distinguishes five basic land categories or types of land use (arable land, meadows, pastures, woodland, and vineyards) as well as land with mixed use (for example, meadows with fruit trees) and land with special uses (for example, hop plantations, marshes, quarries).

The latest digital map of land use (Raba kmetijskih zemljišč, variant 1.0_2002) originated in the framework of the Project for Modernizing the Registration of Property and its subproject Recording and Monitoring Use of Agricultural Land carried out through the cooperation of the Ministry of Agriculture, Forestry, and Food, the Surveying and Mapping Authority of the Republic of Slovenia, the Supreme Court of the Republic of Slovenia, the Ministry of Finance, and the Ministry of Justice. The digital map is augmented by a database that links the register of farms, the land cadastre, and the land register. It was created for determining the size of subsidies relative to the size of farms (Lipej 2001).

The sources of data for the map were 1:5000-scale digital orthophotographs based on black-and-white 1:17,500-scale aerial photographs and field verification. The subproject began in 1998 when types of land use were interpreted on fifty model sheets on whose basis an interpretation key was defined and each type of land use was delimited vectorially. The project was completed in 2002 with the integration of all digital orthophotographs into one map (Rotter 2001). Its weakness is in the non-uniform time frame for the collection of data (via photographs) from the various regions of Slovenia. For this reason data on land use for about a third of the territory of Slovenia were revised and updated. (Dejanska raba kmetijskih zemljǐ̌č, variant Raba_beta_20050408). It was this latest version that we relied on in our own analyses.

The map shows 22 distinct types of land use:

- crop-fields and gardens,

- temporary meadows

- hop plantations,

- vineyards,

- intensive orchards,

- extensive orchards,

- olive groves,

- other permanent plantations,

- permanent meadows and pastures,

- marshy meadows,

- areas of overgrowth

- plantations of forest trees, 
- woodland and brushland,

- agricultural land overgrown by woodland

- forest

- built-up and related areas,

- marshlands,

- reedbeds,

- other wetlands,

- dry open land with specific vegetation cover,

- open areas with negligible or no vegetation cover,

- areas of water.

For the purposes of our study, we combined these twenty-two basic types of land use into seven categories of land use:

- arable land (includes crop-fields and gardens, temporary meadows and hop plantations),

- vineyards and similar permanent plantations (includes vineyards, olive groves, and other permanent plantations),

- orchards (includes intensive and extensive orchards)

- grasslands (includes permanent meadows and pastures and marshland meadows),

- woodlands (includes overgrown areas, tree plantations, woodland and brushland, agricultural areas overgrown by woodland),

- built-up areas (includes built-up and related areas),

- areas with other types of land use (includes marshlands, reedbeds, other types of wetlands and marshlands, dry open land with specific vegetation cover, open land with negligible or no vegetation cover, and areas of water).

Based on these combined categories, we prepared a map of groups of types of land use modified from the map of basic types of land use and installed it in the Geographical Information System as a new layer, and linked it to the digital elevation model.

Hereafter, the simplified expression »types of land use « is employed rather than the expression "groups of types of land use«.

The chosen sectors of Tertiary low hills differ greatly among themselves with respect to relief and other natural features; other natural and social factors, in addition to the rock substrate and relief, have an impact on land use. This is confirmed by a comparison of the different proportions of land use types among the selected areas. Arable land in the Goričko sector takes up as much as a third of the entire area, while in

Table 2: Combined types of land use in selected areas of Tertiary hills.

\begin{tabular}{lrrrrrrr}
\hline & arable land & vineyards & orchards & grassland & woodland & other & total \\
\hline in ha & & & & & & & \\
\hline Bočaji (Koprska brda) & 8421 & 10,655 & 209 & 26,691 & 102,439 & 5185 & 153,600 \\
Pregarje (Brkini) & 2306 & 102 & 5519 & 22,755 & 120,090 & 2828 & 153,600 \\
Imenje (Goriška brda) & 1045 & 51,175 & 17,038 & 10,784 & 63,932 & 9626 & 153,600 \\
Kočice (Haloze) & 6447 & 4079 & 6562 & 44,550 & 85,920 & 6042 & 153,600 \\
Pršetinci (Slovenske gorice) & 39,335 & 7785 & 5341 & 27,055 & 63,250 & 10834 & 153,600 \\
Markovci (Goričko) & 50,814 & 537 & 3196 & 24,194 & 68,726 & 6133 & 153,600 \\
\hline in \% & & & & & & & \\
\hline Bočaji (Koprska brda) & 5.48 & 6.94 & 0.14 & 17.38 & 66.69 & 3.38 & 100.00 \\
Pregarje (Brkini) & 1.50 & 0.07 & 3.59 & 14.81 & 78.18 & 1.84 & 100.00 \\
Imenje (Goriška brda) & 0.68 & 33.32 & 11.09 & 7.02 & 41.62 & 6.27 & 100.00 \\
Kočice (Haloze) & 4.20 & 2.66 & 4.27 & 29.00 & 55.94 & 3.93 & 100.00 \\
Pršetinci (Slovenske gorice) & 25.61 & 5.07 & 3.48 & 17.61 & 41.18 & 7.05 & 100.00 \\
Markovci (Goričko) & 33.08 & 0.35 & 2.08 & 15.75 & 44.74 & 3.99 & 100.00 \\
\hline Mediterranean sectors total & 2.55 & 13.44 & 4.94 & 13.07 & 62.17 & 3.83 \\
Pannonian sectors total & 20.96 & 2.69 & 3.28 & 20.79 & 47.29 & 4.99 & 100.00 \\
\hline Mediterranean low hills total & 7.96 & 6.8 & 3.56 & 18.18 & 55.45 & 8.05 & 100.00 \\
Pannonian low hills total & 21.77 & 4.17 & 2.94 & 21.99 & 41.56 & 7.57 & 100.00 \\
\hline
\end{tabular}


Legend for figures 9 to 14: arable land - brown, vineyards - purple, orchards - yellow, grasslands - light green, woodlands - dark green, built-up areas - red, other areas - blue.

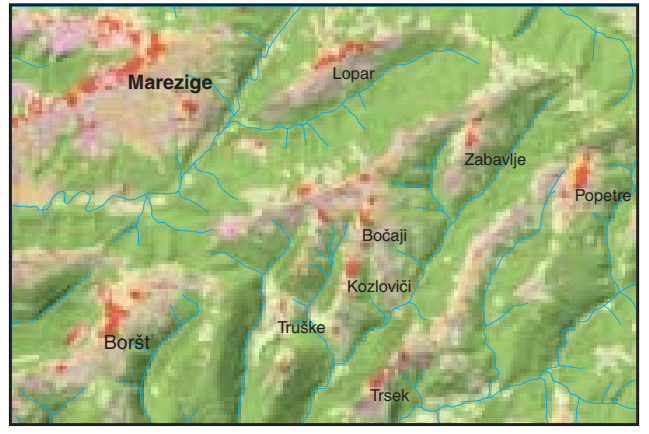

Figure 9: Land use in the area around Bočaji, in the Koprska brda region.

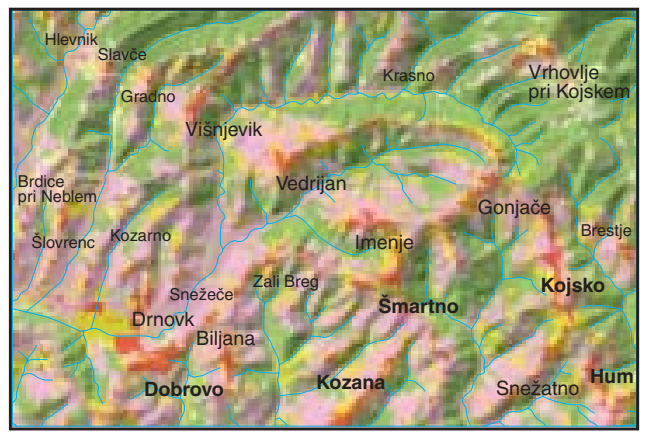

Figure 11: Land use in the area around Imenje, in the Goriška brda region.

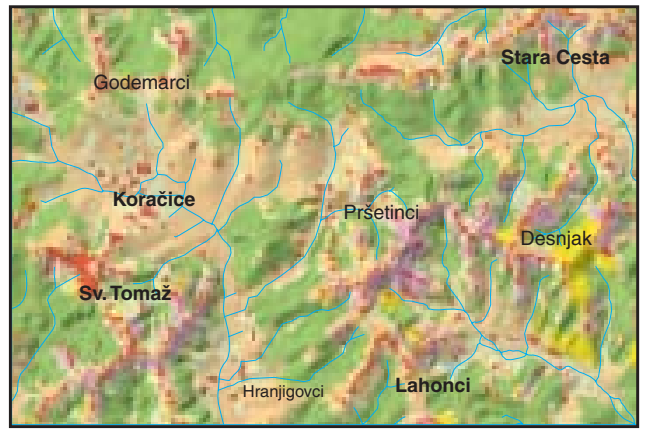

Figure 13: Land use in the area around Pršetinci, in the Slovenske gorice region.

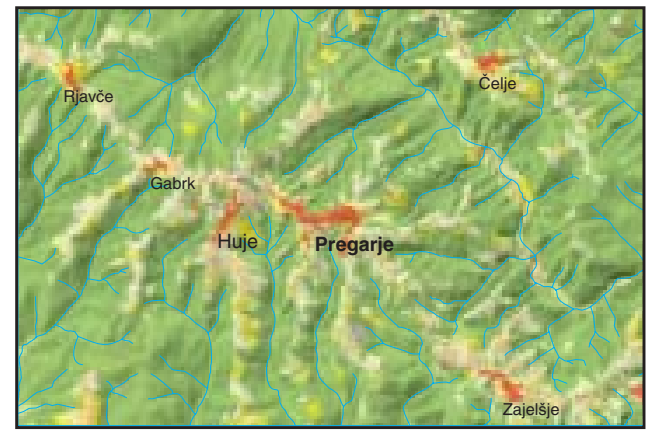

Figure 10: Land use in the area around Pregarje, in the Brkini region.

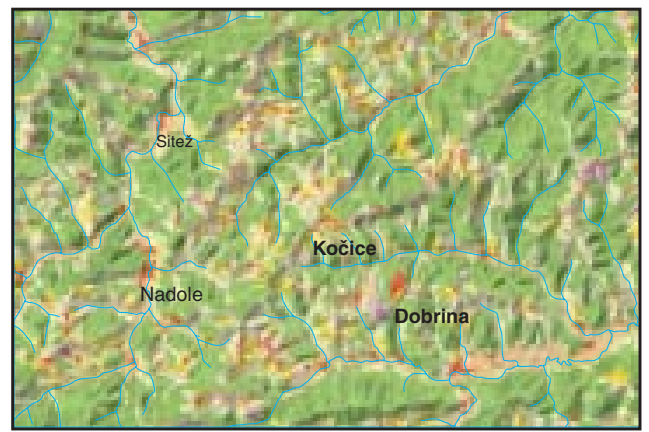

Figure 12: Land use in the area around Kočice, in the Haloze region.

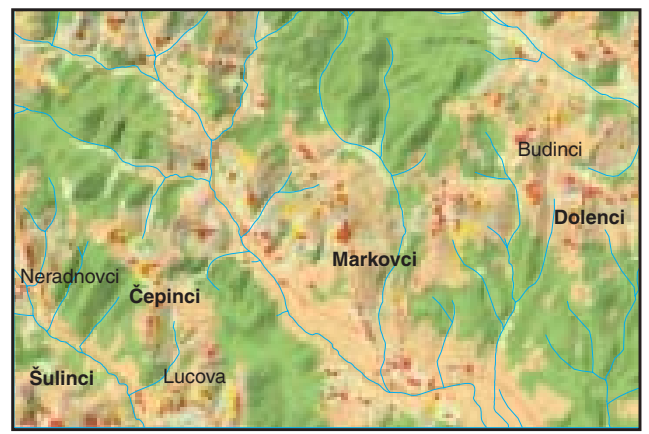

Figure 14: Land use in the area around Markovci, in the Goričko region. 
Goriška brda it makes up less than one percent. Just the opposite is true in comparing vineyards. The Goriška brda sector stands out for having the highest share of orchards, while in the Koprska brda sector there are practically none at all. The Haloze sector has twice as many grasslands as the remaining sectors, with the exception of the Goriška brda sector, where this land use category is smallest of all. The Brkini sector stands out for its degree of forest cover, with nearly four-fifths of its surface consisting of woodland; the Slovenske gorice sector has the smallest share, but it is still more than two-fifths. Woodland is the leading category in all sectors, but the second place category varies from sector to sector: grassland in Koprska brda, Brkini, and Haloze, vineyards in Goriška brda, and arable land in Slovenske gorice and Goričko. In all the Mediterranean sectors taken together, woodlands are in first place and vineyards are in second place, while in all the inland sectors taken together woodland is in first place and arable land is in second place. If we take into account all of the Slovene Mediterranean low hills regions, woodland is in first place, followed by grasslands; this is true also of all the Slovene inland low hills regions taken as a whole (Table 2).

\section{Height of the surface}

Taking into consideration the basic types of land use, i. e. arable land, vineyards, orchards, grasslands, and woodlands, and all the sectors in total, we find that with respect to height zones vineyards are the most concentrated, with an average concentration coefficient of 0.5605 , followed by orchards with a coefficient of 0.4944 , then woodland with a coefficient of 0.4445 , and finally arable land with a coefficient of 0.4286 and grassland with a coefficient of 0.3896 .

In the Goriška brda sector, arable lands is most concentrated with respect to fifty-meter height zones, since four-fifths lie in zones between 50 and $150 \mathrm{~m}$, representing less than two-fifths of the total area. Grassland is most evenly distributed.

In the Koprska brda sector orchards are the most concentrated, with two-thirds located in height zones between 300 and $400 \mathrm{~m}$, which represent barely a third of the total area. Arable land is the most evenly distributed.

In the Brkini sector vineyards are most concentrated. Three-fifths of all vineyards are located in the zone between 600 and $650 \mathrm{~m}$, a fifth of the total area. Arable land is most evenly distributed.

In the Haloze sector as well, vineyards are the most concentrated, with nine-tenths located in height zones between 350 and $450 \mathrm{~m}$, representing less than half of all the area. Grassland is the most evenly distributed, with proportions according to height zone almost everywhere the same.

The third area in which vineyards are the most concentrated is the Goričko sector. Four-fifths lie in the height zone between 300 and $350 \mathrm{~m}$, which represents less than half of the total area. Woodland is the most evenly distributed.

In the Slovenske gorice sector, orchards are the most concentrated. Four-fifths of orchards are located in the height zone between 250 and $300 \mathrm{~m}$. Arable land is the most evenly distributed.

In addition to the distribution of land use types according to height zones, it is interesting to look at the concentration of individual types of land use within individual height zones. In the Koprska brda sector the greatest density is achieved by woodlands, which grow over the whole of the height zone between 50 and $100 \mathrm{~m}$, such that their density is 100 ha per $\mathrm{km}^{2}$, in the Goriška brda sector, woodland in the height zone between 300 and $350 \mathrm{~m}$ with a density of 69 ha per $\mathrm{km}^{2}$, in the Brkini sector woodland in the height zone between 450 and 499 with a density of 87 ha per $\mathrm{km}^{2}$, in the Haloze sector woodland in the height zone between 300 and $350 \mathrm{~m}$ with a density of 62 ha per $\mathrm{km}^{2}$ and in the Slovenske gorice sector as well woodland in the height zone between 250 and $300 \mathrm{~m}$ with a density of 47 ha per $\mathrm{km}^{2}$. In the Goričko sector, the greatest density is achieved by arable land in the height zone between 200 and $250 \mathrm{~m}$ with a density of 54 ha per $\mathrm{km}^{2}$.

This is the greatest density of arable land in all sectors. Vineyards have the greatest density in the Goriška brda sector in the height zone between 100 and $150 \mathrm{~m}$ with a density of 43 ha per $\mathrm{km}^{2}$, and orchards also in the Goriška brda sector in the height zone between 50 and $100 \mathrm{~m}$ with a density of 19 ha per $\mathrm{km}^{2}$, grassland in the Brkini sector in the height zone between 750 and $800 \mathrm{~m}$ with a density of 50 ha per $\mathrm{km}^{2}$, and woodland in, as already mentioned, the Koprska brda sector in the elevation zone between 50 and $100 \mathrm{~m}$ with a density of 100 ha per $\mathrm{km}^{2}$. 
Legend for Figures 15 to 20: from $0 \mathrm{~m}$ to $199 \mathrm{~m}$ - shades of green, from $200 \mathrm{~m}$ to $399 \mathrm{~m}$ - shades of yellow, from $400 \mathrm{~m}$ to $599 \mathrm{~m}$ - shades of orange, from $600 \mathrm{~m}$ to $800 \mathrm{~m}$ - shades of red.

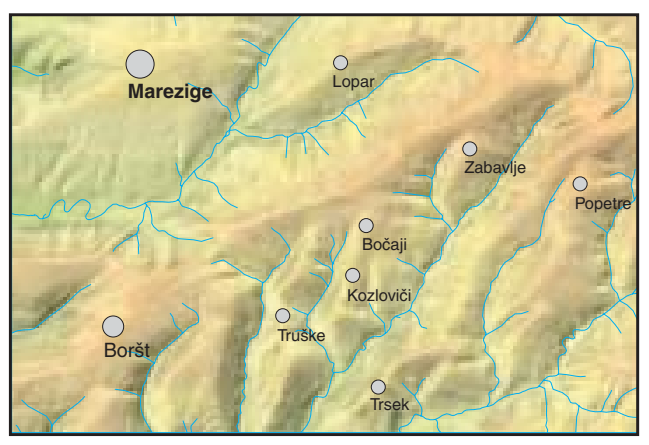

Figure 15: Heights of the area around Bočaji, in the Koprska brda region.

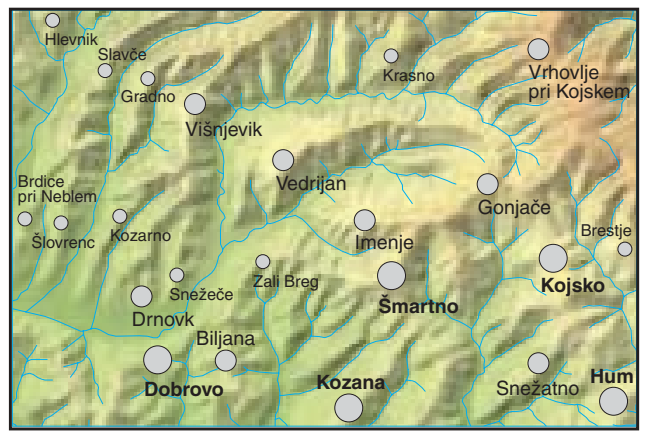

Figure 17: Heights of the area around Imenje, in the Goriška brda region.

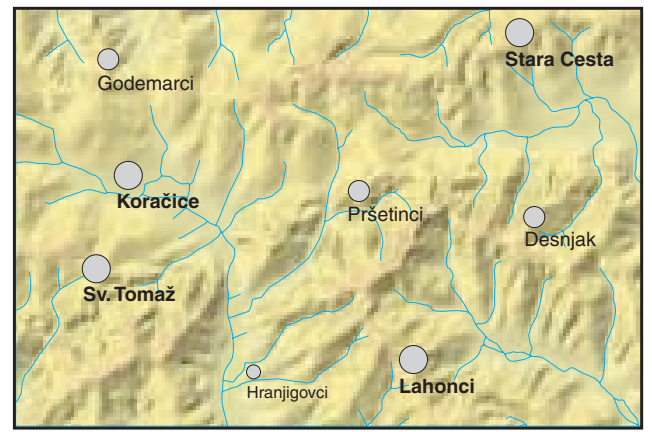

Figure 19: Heights of the area around Pršetinci, in the Slovenske gorice region.

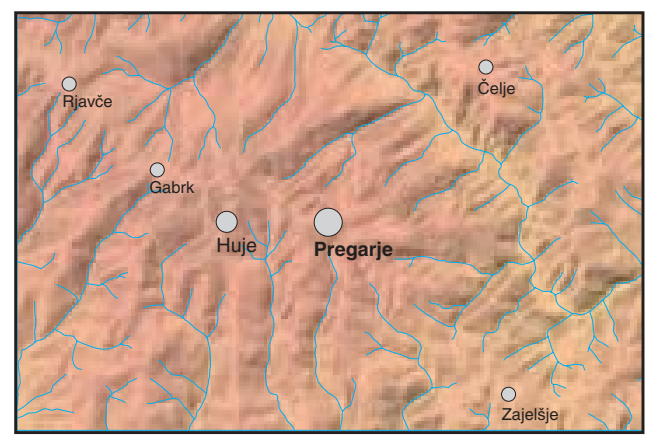

Figure 16: Heights of the area around Pregarje, in the Brkini region.

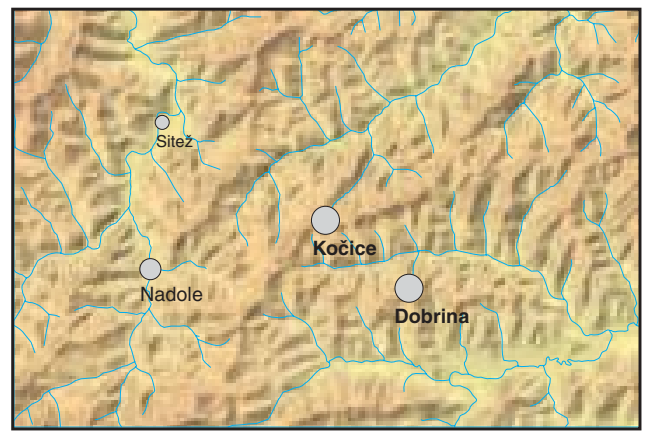

Figure 18: Heights of the area around Kočice, in the Haloze region.

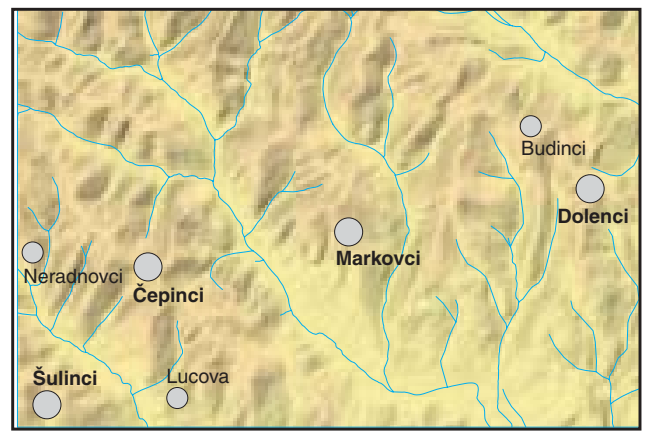

Figure 20: Heights of the area around Markovci, in the Goričko region. 


\section{Slope of the surface}

When we consider all the sectors taken together, orchards are the most concentrated with respect to slope, with an average coefficient of 0.4913 , followed by vineyards with a coefficient of 0.4852 , woodland with a coefficient of 0.4384 , and finally arable with a coefficient of 0.4380 and grassland with a coefficient of 0.4184 . The differences among the coefficients are smaller for slope than for height zones.

In the Goriška brda sector woodlands are the most concentrated with respect to slope: four-fifths are located in the slope class below $6^{\circ}$, which represents barely a tenth of the total area. Grassland is the most evenly distributed.

In the Koprska brda sector arable land is the most concentrated, with nine-tenths of it located in slope classes between 2 and $12^{\circ}$, which represent less than half of the total area of the sector. Woodland is the most evenly distributed.

In the Brkini sector vineyards are the most concentrated. Four-fifths lie in slope classes between 2 and $12^{\circ}$ although these classes make up less than a third of the total area. Woodland is the most evenly distributed.

In the Haloze sector, orchards are the most concentrated, with four-fifths located in slope classes between 12 and $30^{\circ}$, which represent less than a third of the total area. Arable land is the most evenly distributed.

In the Slovenske gorice sector, too, orchards are the most concentrated. Three-fourths of orchards lie in slope classes between 6 and $30^{\circ}$. Grassland is the most evenly distributed.

The third area in which orchards are the most concentrated is the Goričko sector. More than nine-tenths of orchards lie in slope classes between 2 and $12^{\circ}$. Arable land is the most evenly distributed.

In addition to the distribution of land use types according to slope classes, it is interesting to look at the concentration of individual types of land use within individual slope classes.

In all sectors woodland achieved the highest density: in the Koprska brda sector in the slope class of more than $30^{\circ}$ with a density of 98 ha per $\mathrm{km}^{2}$, in Goriška brda sector in the same slope class with a density of 90 ha per $\mathrm{km}^{2}$, in the Brkini sector also in the same class with a density as high as 100 ha per $\mathrm{km}^{2}$, and in the Haloze sector in the same class with a density of 80 ha per $\mathrm{km}^{2}$. In the Slovenske gorice sector woodland in the slope class between 20 and $30^{\circ}$ had a density of 71 ha per $\mathrm{km}^{2}$ and in the Goričko sector in the same slope class they achieved a density of 85 ha per $\mathrm{km}^{2}$.

Arable land has the greatest density in the Goričko sector in the slope class under $2^{\circ}$ with a density of 56 ha per $\mathrm{km}^{2}$, vineyards have the greatest density in the Goriška brda sector in the slope class between 6 and $12^{\circ}$ with a density of 44 ha per $\mathrm{km}^{2}$, orchards likewise in the Goriška brda sector in the slope class below $2^{\circ}$ with a density of 20 ha per $\mathrm{km}^{2}$, grassland in the Brkini sector in the slope class below $2^{\circ}$ with a density of 36 ha per $\mathrm{km}^{2}$, and woodland also in the Brkini sector, in the slope class above $30^{\circ}$ with a density of 100 ha per $\mathrm{km}^{2}$.

Legend for figures 21 to 26 : from $0^{\circ}$ to $2^{\circ}$ - dark green, from $2^{\circ}$ to $6^{\circ}$ - light green, from $7^{\circ}$ to $12^{\circ}$ - yellow, from $13^{\circ}$ to $20^{\circ}-$ light red and from $21^{\circ}$ and steeper - dark red.

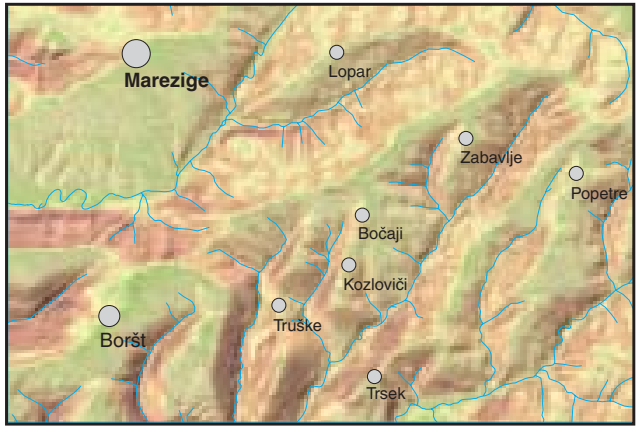

Figure 21: Slopes of the area around Bočaji, in the Koprska brda region.

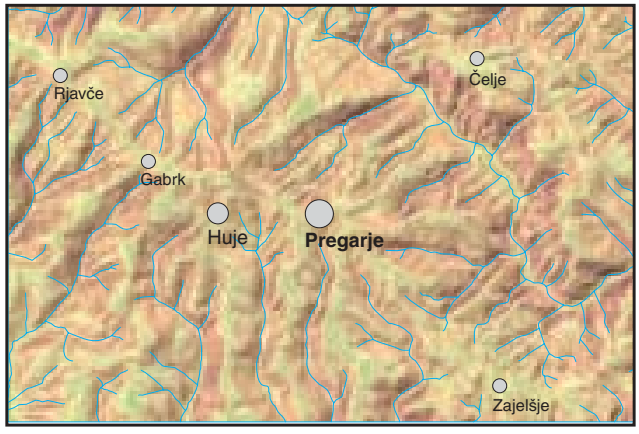

Figure 22: Slopes of the area around Pregarje, in the Brkini region. 


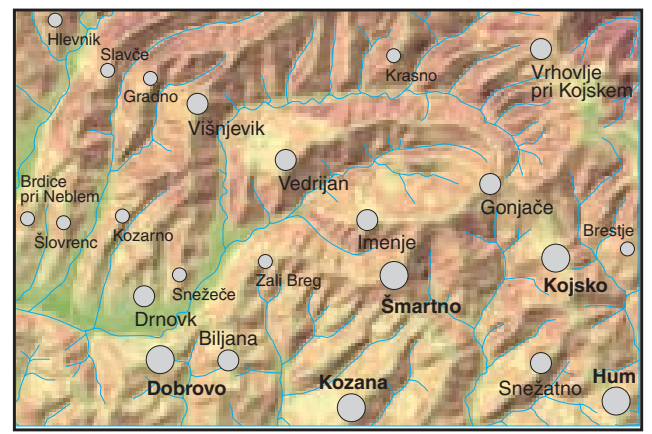

Figure 23: Slopes of the area around Imenje, in the Goriška brda region.

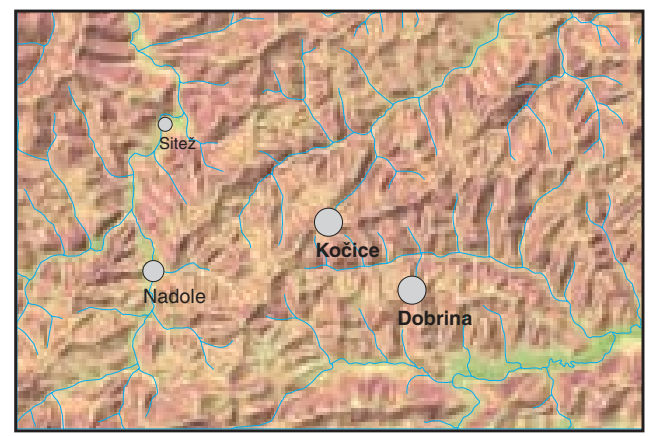

Figure 24: Slopes of the area around Kočice, in the Haloze region.

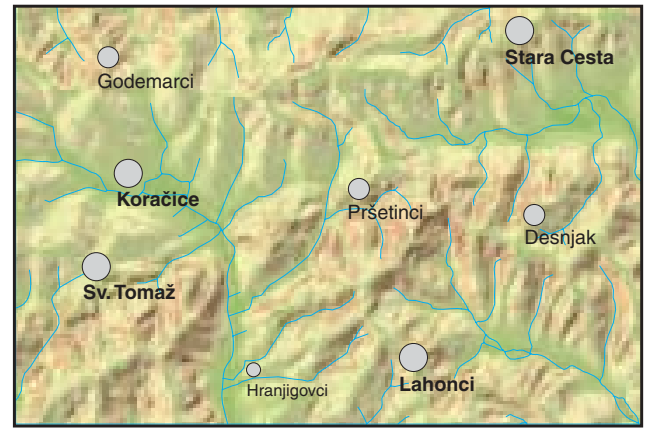

Figure 25: Slopes of the area around Pršetinci, in the Slovenske gorice region.

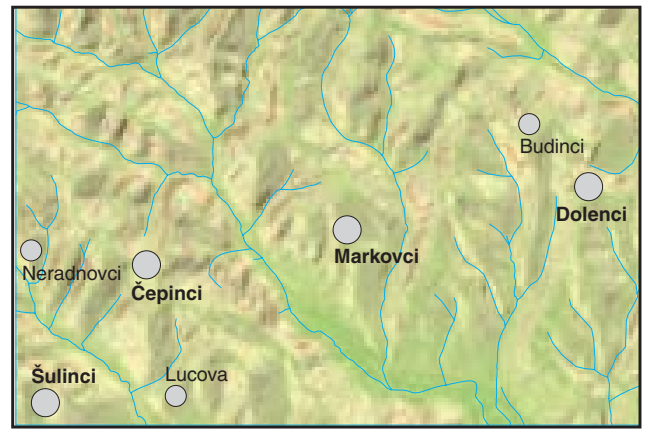

Figure 26: Slopes of the area around Markovci, in the Goričko region.

\section{Aspect of the surface}

Taking all the sectors together, we see that with respect to aspect classes, vineyards are the most concentrated with an average concentration coefficient of 0.4755 , followed by arable land with a coefficient of 0.3001 , orchards with a coefficient of 0.2219 , grassland with a coefficient of 0.2042 and woodland with a coefficient of barely 0.1001 . Vineyards stand out: the ratio between the coefficient for vineyards and that for woodland with respect to aspect of the surfaces is almost 5:1, whereas the coefficients with respect to slopes are practically identical.

In the Goriška brda sector arable land is the most concentrated with respect to aspect classes, and woodland is the most evenly distributed. In the Koprska brda, Brkini, Haloze and Goričko sectors, vineyards are the most concentrated and woodland is the least concentrated, while in the Slovenske gorice sector vineyards are the most concentrated and orchards are the least concentrated with respect to aspect classes.

In addition to the distribution of types of land use with respect to aspect classes, the density of individual types of land use within particular aspect classes is also of interest.

In all sectors with the exception of Goričko the greatest density was found for woodlands with a northern aspect. In the Koprska brda sector their density is 79 ha per $\mathrm{km}^{2}$, in the Goriška brda sector 49 ha per $\mathrm{km}^{2}$, in the Brkini sector 82 ha per $\mathrm{km}^{2}$, in the Haloze sector $77 \mathrm{ha}$ per $\mathrm{km}^{2}$ and in the Slovenske gorice sector 51 ha per $\mathrm{km}^{2}$. In the Goričko sector the greatest density of woodlands, 49 ha per $\mathrm{km}^{2}$, was found in locations with eastern and western aspects. 
Legend for Figures 27 to 32: northern aspect - purple, eastern and western aspect - orange, southern aspect - yellow.

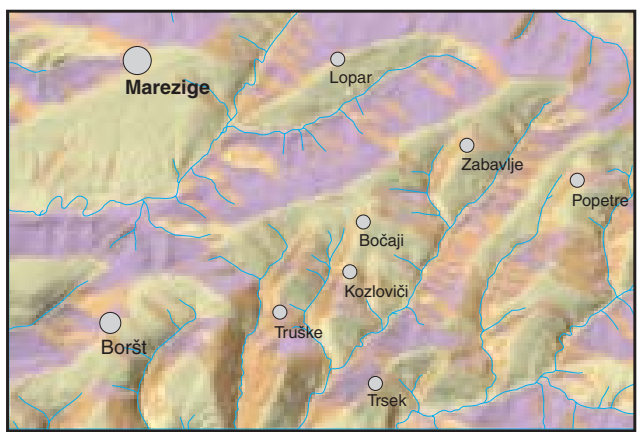

Figure 27: Aspect of the area around Bočaji, in the Koprska brda region.

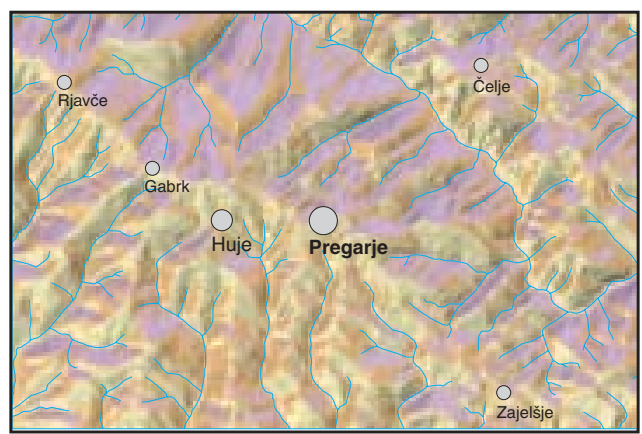

Figure 28: Aspect of the area around Pregarje, in the Brkini region.

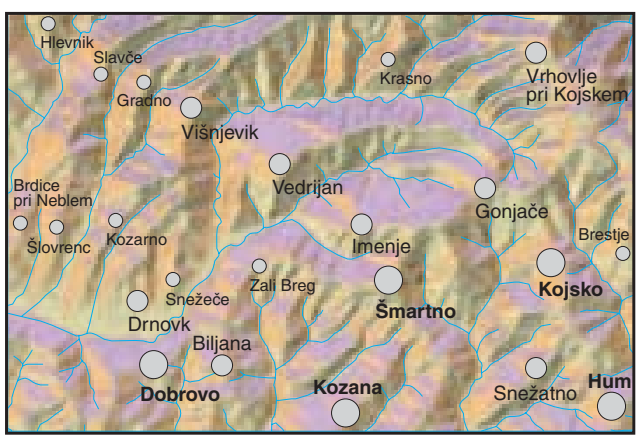

Figure 29: Aspect of the area around Imenje, in the Goriška brda region.

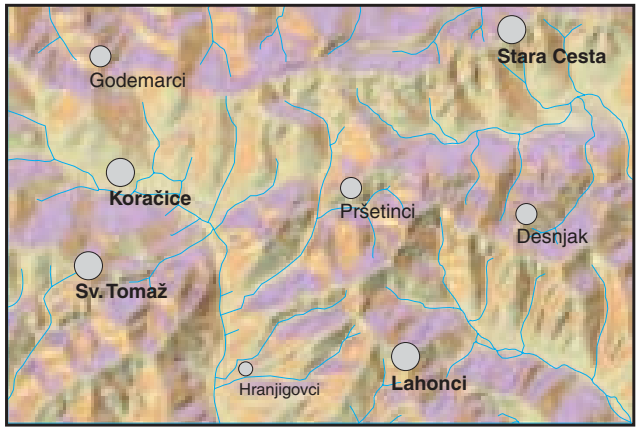

Figure 31: Aspect of the area around Pršetinci, in the Slovenske gorice region.

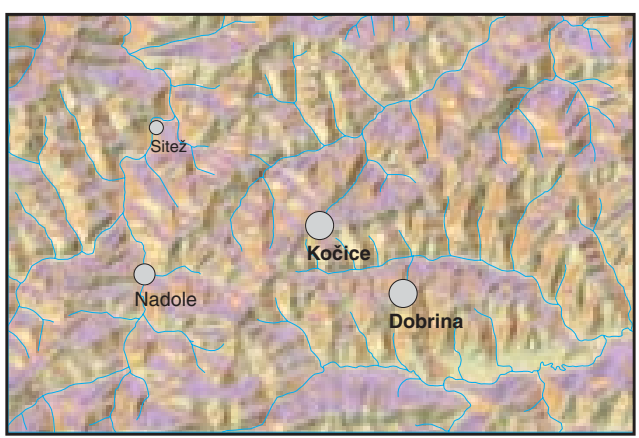

Figure 30: Aspect of the area around Kočice, in the Haloze region.

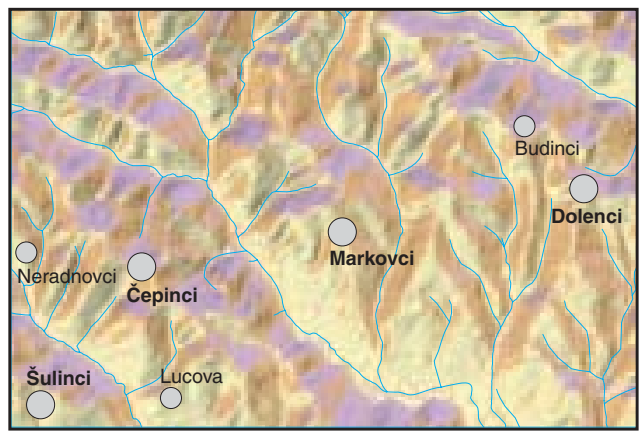

Figure 32: Aspect of the area around Markovci, in the Goričko region. 
In the Goričko sector, arable land has the highest concentration in areas with southerly aspects, with a density of 37 ha per $\mathrm{km}^{2}$, while in the Goriška brda sector vineyards in areas with eastern and western aspects attain a density of 36 ha per $\mathrm{km}^{2}$, and orchards in areas with southern aspects have a density of $13 \mathrm{ha}$ per $\mathrm{km}^{2}$. In the Haloze sector, grasslands with southerly aspect have a density of 41 ha per $\mathrm{km}^{2}$, and woodlands, as already mentioned, in the Brkini sector in areas with northern aspect have a density of 82 ha per $\mathrm{km}^{2}$.

Also of interest is the variation in density of individual aspect classes according to different types of land use. The density of areas with northern aspect is in all sectors greatest for woodlands, in the case of the Haloze sector 43 ha of northern aspect per $\mathrm{km}^{2}$ of woodlands. The lowest density in all sectors is found in vineyards, and is for example in the Brkini sector only 1 ha of northern aspect per $\mathrm{km}^{2}$ of vineyards, except for the Goričko sector, where the lowest density is found for arable land.

The density of areas with southern aspect in the Koprska brda, Haloze, and Goričko sectors is greatest among vineyards. For example, in the Koprska brda sector, for every $\mathrm{km}^{2}$ of vineyard area, 76 ha have a southern aspect. In the Goriška brda sector the greatest density of such areas is found for arable land: for every $\mathrm{km}^{2}$ of arable land, 53 ha have a southern aspect. In the Brkini sector, the greatest density of such areas is found in the land use category of orchards: 46 ha with southern aspect per $\mathrm{km}^{2}$ of orchards. The lowest density in all sectors is found among woodlands. For example in the Haloze sector only 21 ha out of every $\mathrm{km}^{2}$ of woodlands have a southern aspect. The Brkini represents an exception: surprisingly, only 14 ha per $\mathrm{km}^{2}$ of vineyards have a southern aspect.

\section{Potential erosion risk of the surface}

Considering all the sectors together, with respect to erosion risk classes vineyards are the most concentrated, with an average concentration coefficient of 0.6619 , followed by woodlands with a coefficient of 0.6388 , orchards with a coefficient of 0.6051 , grasslands with a coefficient of 0.5976 and arable land with a coefficient of 0.5651 . The coefficients do not differ greatly among themselves, and in comparison to the coefficients for height, slope, and aspect they are very high.

In the Goriška brda sector vineyards show the most concentration with respect to erosion risk classes, with three-fourths located in the weak erosion class, while arable land is most evenly distributed among the classes.

Similarly, in the Koprska brda sector vineyards show the most concentration, with three-fourths found on land classified in the weak erosion class. In this sector orchards are most evenly distributed.

In the Brkini sector, too, vineyards are the most concentrated, with nine-tenths of them located on land in the weak erosion class. Grasslands are most evenly distributed.

The same pattern holds true for the Slovenske gorice sector. Vineyards are the most concentrated, with two-thirds in the weak erosion class, and grasslands are the most evenly distributed.

In the Haloze sector orchards show the most concentration. Four-fifths are in the weak erosion class. Arable land is most evenly distributed.

Surprisingly, in the Goričko sector grasslands show the most concentration: two-thirds lie in the class of weak erosion. Arable land is most evenly distributed.

The densities of individual types of land use in different erosion classes is also of interest in addition to the distribution of types of land use by erosion class.

In the Goriška brda sector the greatest density is achieved by woodlands in the class of strong erosion at 92 ha per $\mathrm{km}^{2}$, in the Koprska brda sector the density of woodlands in this class is even 99 ha per $\mathrm{km}^{2}$, in the Brkini sector the density of woodlands in the class of strong erosion is likewise 99 ha per $\mathrm{km}^{2}$, in the Haloze sector it is 88 ha per $\mathrm{km}^{2}$ and in the Slovenske gorice sector it is 69 ha per $\mathrm{km}^{2}$. In the Goričko sector the greatest density is achieved by grasslands in the strong erosion class: 100 ha per $\mathrm{km}^{2}$.

This is the greatest density shown by grasslands in any sector. The greatest density of arable land is in the Goričko sector in the class of negligible erosion, with 41 ha per $\mathrm{km}^{2}$, of vineyards in the Goriška brda sector in the class of negligible erosion with 40 ha per $\mathrm{km}^{2}$, of orchards also in the Goriška brda sector in the class of negligible erosion with 13 ha per $\mathrm{km}^{2}$, and of woodlands in the Brkini sector in the class of strong erosion with $99 \mathrm{ha}$ per $\mathrm{km}^{2}$. 
Legend for Figures 33 to 38: negligible erosion - yellow, weak erosion - orange, moderate erosion - light red, powerful erosion - dark red.

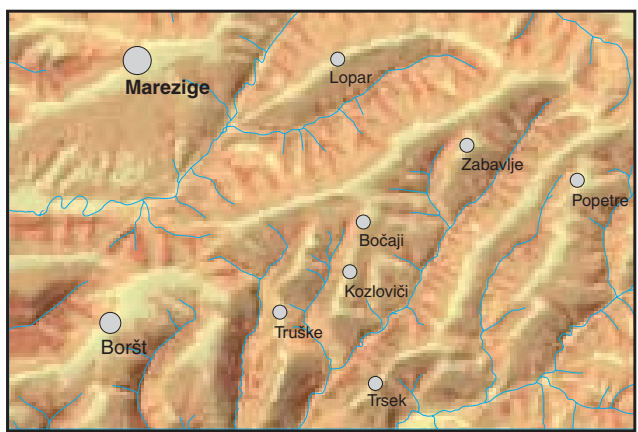

Figure 33: Erosion risk of the area around Bočaji, in the Koprska brda region.

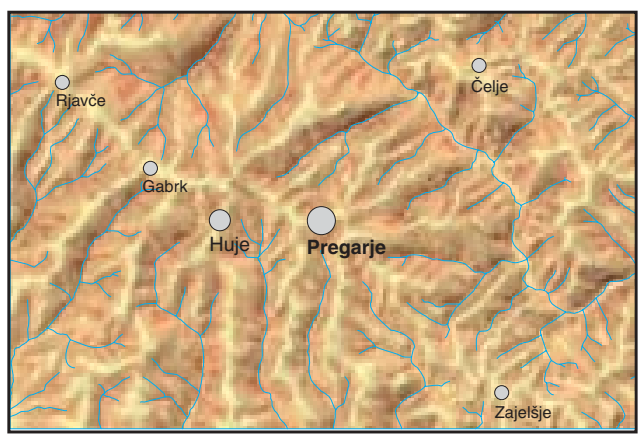

Figure 34: Erosion risk of the area around Pregarje, in the Brkini region.

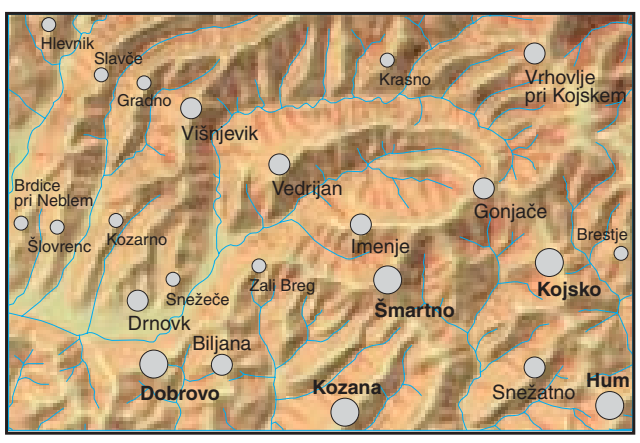

Figure 35: Erosion risk of the area around Imenje, in the Goriška brda region.

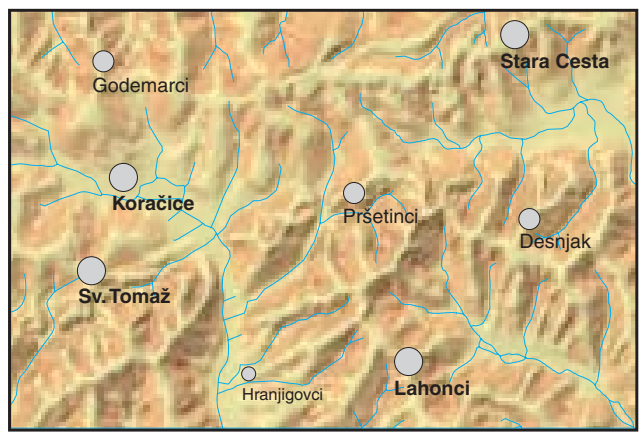

Figure 37: Erosion risk of the area around Pršetinci, in the Slovenske gorice region.

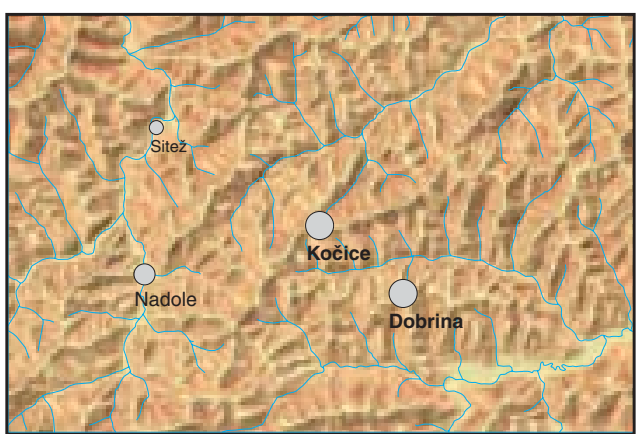

Figure 36: Erosion risk of the area around Kočice, in the Haloze region.

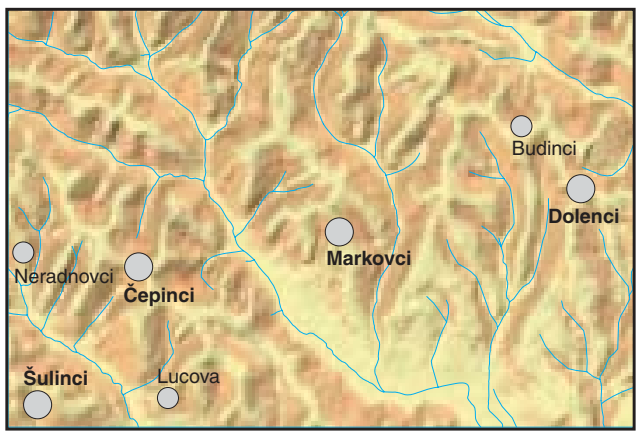

Figure 38: Erosion risk of the area around Markovci, in the Goričko region. 
The density of arable land in all sectors is highest in the class of negligible erosion, and decreases as erosion risk increases. The density of arable land in the strong erosion class in the Haloze sector is less than 1 ha per $\mathrm{km}^{2}$, and is not found at all in this class in other sectors. The densities of vineyards and are in all sectors greatest in the classes of negligible or weak erosion. The density of grasslands varies least with respect to erosion class. In the Goriška brda, Koprska brda and Brkini sectors the density decreases as erosion risk increases, while in the Haloze, Slovenske gorice and Goričko sectors it increases or remains roughly the same. This is an observable difference between the littoral and the inland sectors. The change in density in individual erosion classes with respect to different types of land use is also of interest. The density of areas with negligible erosion is in all sectors greatest for arable land. For example, in the Brki$\mathrm{ni}$ sector it is $67 \mathrm{ha}$ per $\mathrm{km}^{2}$ of arable land. It is least of all for woodland - for example only 8 ha per $\mathrm{km}^{2}$ of woodland in the Brkini sector - with the exception of the Goričko sector, where grasslands show the lowest density in this class.

The density of areas with weak erosion is greatest in all littoral sectors for vineyards. For example, in the Brkini sector, 87 ha per $\mathrm{km}^{2}$ of vineyards are in this class. For the inland sectors, it is greatest for orchards, grassland, and woodland: in the Haloze sector 80 ha per $\mathrm{km}^{2}$ of orchards lie in this class, in the Slovenske gorice sector, 68 ha per $\mathrm{km}^{2}$ of woodland belong in this class and in the Goričko sector 64 ha per $\mathrm{km}^{2}$ of grassland are in this class.

In areas with moderate erosion, woodlands have the greatest density in all sectors except Goričko, where grassland leads. It is lowest of all for vineyards, with the exception of Goričko, where orchards have the lowest density in this class.

The density of areas with strong erosion is greatest for woodland, with the exception of Goričko, where grassland stands out. However, since in the Goričko sector only $0.01 \%$ of all surfaces belong in the class of strong erosion, the data in this class for this sector should be taken with reservations.

\section{Conclusion}

In the Goriška brda, Brkini and Goričko sectors, there are no pronounced patterns in the variability of the individual shares of different types of land use with respect to increased height of the land surface. In the Koprska brda sector, broadly speaking the shares of arable land and woodland decrease, the shares of orchards and grassland increase, and the share of vineyards remains the same as height increases. In the Slovenske gorice sector the shares of arable land and grassland decrease, the shares of vineyards, orchards, and grassland increase, and the share of woodland is greatest at middle heights. In the Haloze sector only the share of vineyards clearly changes with height: it increases as height increases.

An increase in slope in all sectors is correlated only with a marked decrease in the share of arable land and a marked increase in the share of woodland. An increase in aspect from north towards the south is correlated with a decrease in the share of woodland and an increase in the share of vineyards in all sectors except Goriška brda, Brkini and Slovenske gorice, where the share of vineyards in areas with southern aspect is somewhat smaller than in areas with eastern and western aspect, but is still considerably greater than in areas with northern aspect. An increase in erosion risk potential is in all sectors correlated with an increase in the share of woodland and a decrease in the share of arable land; in Mediterranean low hills areas the shares of vineyards, orchards, and grassland also drop.

In inland low hills areas, the main indicators of the significance of relief are arable land, which is linked to favorable relief conditions, and woodland, which is linked to poor relief conditions. In Mediterranean low hills areas it is reflected also in vineyards and orchards, which are linked to favorable relief conditions. The ratios between arable land, vineyards, and orchards on the one hand, and woodland on the other, are as follows in the Goriška brda sector: in areas with negligible erosion risk it is approximately 4:1, and in areas with strong erosion risk it is $1: 15$. In the Koprska brda sector the same ratios are 1:1 and 1:860, in the Brkini sector 1:3 and 1:503, in the Haloze sector $1: 1$ and 1:71, in the Slovenske gorice sector 2:1 and 1:6, and in the Goričko sector 1:1 and 1:4 (in the last two sectors the second ratio is for areas with moderate erosion risk, since in areas with strong erosion risk there are no areas of arable land, vineyards, and orchards).

The correlation coefficients show that the connection between land use and potential erosion risk is higher in Mediterranean low hills areas (Brkini 0.2420, Koprska brda 0.2336, Goriška brda 0.2227) than in inland low hills areas (Slovenske gorice 0.2144, Haloze 0.1846, Goričko 0. 1172). 
In the Haloze sector land use is most closely correlated with the aspect of the land surface and in the Slovenske gorice sector it is most closely correlated with the height of the land surface. In the other sectors, potential erosion risk is most important. In the Slovenske gorice sector potential erosion risk is in second place; in all other sectors slope of the surface is in second place.

An evaluation of correlation coefficients between land use and individual relief indicators for all of Slovenia (Perko 1998; Perko 2001; Hrvatin and Perko 2003) has shown that land use is most closely correlated with height of the land surface, followed by slope and to a lesser degree aspect. In Mediterranean and inland low hills areas with a significant share of vineyards, slope and aspect of the land surface are more important than height of the surface. In general land use in Mediterranean low hills is more adapted to the potential erosion risk than in inland low hills, but even in Mediterranean areas it is still not optimal.

In evaluating the results of the analysis of relief indicators and the types of land use it is necessary to take into account the degree of accuracy of the DEM 12.5 (Podobnikar 2006) and the map of land use (Dejanska raba ... 2005) and at the same time be aware that the characteristics and patterns described apply only to the correlation between surface morphology and land use in the areas selected for study.

\section{References}

Blejec, M. 1976: Statistične metode za ekonomiste. Ljubljana.

Dejanska raba kmetijskih zemljišč, različica Raba_beta_20050408. Ministrstvo za kmetijstvo, gozdarstvo in prehrano Republike Slovenije. Ljubljana, 2005.

Eastman, J. R. 1995: IDRISI for Windows. User's Guide. Worcester.

Gabrovec, M., Kladnik, D. 1997: Nekaj novih vidikov rabe tal v Sloveniji. Geografski zbornik 37. Ljubljana.

Gabrovec, M., Kladnik, D., Petek, F. 2001: Land Use Changes in the $20^{\text {th }}$ Century in Slovenia. Land Use/Cover Changes in Selected Regions in the World. Volume I. Asahikawa.

Hrvatin, M., Perko, D. 2002: Ugotavljanje ukrivljenosti površja z digitalnim modelom višin in njena uporabnost v geomorfologiji. Geografski informacijski sistemi 2001-2002. Ljubljana.

Hrvatin, M., Perko, D. 2003: Gozdno rastje in morfometrične značilnosti površja v Sloveniji. Geografski vestnik 75-2. Ljubljana.

Hrvatin, M., Perko, D. 2003: Surface Roughness and Land Use in Slovenia. Acta geographica Slovenica 43-2. Ljubljana.

Interpretacijski ključ, podrobno pojasnilo posameznih klasifikacijskih razredov, ki so se uporabljali pri projektu Zajem rabe kmetijskih zemljišč. Projekt posodobitve evidentiranja nepremičnin, Podprojekt D: Zajem in spremljanje rabe kmetijskih zemljišč. Ministrstvo za kmetijstvo, gozdarstvo in prehrano Republike Slovenije. Ljubljana, 2002.

Kladnik, D., Gabrovec, M. 1998: Raba tal. Geografski atlas Slovenije. Ljubljana.

Kladnik, D., Ravbar, M. 2003: Členitev slovenskega podeželja. Geografija Slovenije 8. Ljubljana.

Komac, B., Zorn, M. 2005: Soil erosion on agricultural land in Slovenia - measurements of rill erosion in the Besnica valley. Acta geographica Slovenica 45-1. Ljubljana.

Lipej, B. 2001: Državni projekti na področju evidentiranja nepremičnin. Geodetski vestnik 45-3. Ljubljana.

Lindsay, J. B., 2005: The Terrain Analysis System: a tool for hydro-geomorphic applications. Hydrological processes 19. Chichester.

McCoy, J., Johnston, K. 2001: Using ArcGIS Spatial Analyst. Redlands.

Oštir, K., Podobnikar, T., Stančič, Z., Mlinar, J. 2000: Digitalni model višin Slovenije InSAR DMV 25. Geodetski vestnik 44-4. Ljubljana.

Perko, D. 1998: The regionalization of Slovenia. Geografski zbornik 38. Ljubljana.

Perko, D. 2001: Analiza površja Slovenije s stometrskim digitalnim modelom reliefa. Geografija Slovenije 3. Ljubljana.

Perko, D. 2002: Določanje vodoravne in navpične razgibanosti površja z digitalnim modelom višin. Geografski vestnik 74-2. Ljubljana.

Petek, F. 2002: Methodology of Evaluation of Changes in Land Use in Slovenia between 1896 and 1999. Geografski zbornik 42. Ljubljana. 
Petek, F. 2005a: Spremembe rabe tal v slovenskem alpskem svetu. Geografija Slovenije 11. Ljubljana.

Petek, F. 2005b: Tipology of Slovenia's Alpine Region with emphasis on Land Use and Changes in Land Use. Acta geographica Slovenica 45-1. Ljubljana.

Podobnikar, T. 2002: Koncept izdelave novega digitalnega modela reliefa Slovenije. Geografski vestnik 74-1. Ljubljana.

Podobnikar, T. 2005: Production of integrated digital terrain model from multiple datasets of different quality. International Journal of Geographical Information Science 19-1. London.

Podobnikar, T. 2006: Digitalni model reliefa iz različnih podatkov. Življenje in tehnika 57-4. Ljubljana.

Podobnikar, T., Oštir, K. 1999: InSAR DMV 25. Ljubljana.

Raba kmetijskih zemljišč, različica 1.0_2002. Ministrstvo za kmetijstvo, gozdarstvo in prehrano Republike Slovenije. Ljubljana, 2002.

Rotter, A. 2001: Zajem rabe kmetijskih zemljišč v okviru Projekta posodobitve evidentiranja nepremičnin. Zbornik Uporaba informacij o pokrovnosti in rabi prostora pri varstvu okolja in trajnostnem razvoju. Ljubljana.

Shaner, J., Wrightsell, J. 2000: Editing in ArcMap. Redlands.

Topole, M. 1998: Mirnska dolina: regionalna geografija porečja Mirne na Dolenjskem. Ljubljana.

Topole, M. 2003: Geografija občine Moravče. Geografija Slovenije 7. Ljubljana.

Tucker, C. 2000: Using ArcToolbox. Redlands.

Urbanc, M. 2002: Kulturne pokrajine v Sloveniji. Geografija Slovenije 5. Ljubljana. 


\section{Raba tal na izbranih erozijsko ogroženih območjih terciarnih gričevij v Sloveniji}

UDK: 551.43:711.14(497.4)

COBISS: 1.01

IZVLEČEK: V prispevku ugotavljamo potencialno erozijsko ogroženost zemljišč glede na izoblikovanost površja in njeno povezanost $\mathrm{z}$ razporeditvijo posameznih vrst rabe tal. Povezave med reliefnimi dejavniki erozijske ogroženosti (nadmorska višina, naklon in ekspozicija površja) in vrstami rabe tal (njive, vinogradi, sadovnjaki, travniki, gozdovi ter pozidana in ostala zemljišča) smo raziskovali v šestih, $24 \mathrm{~km}^{2}$ velikih izsekih iz območij terciarnih gričevij v Sloveniji: Koprskih brd, Brkinov, Goriških brd, Haloz, Slovenskih goric in Goričkega, ki so zaradi prevlade erozijsko slabo odpornih kamnin še posebej zanimiva. Potencialno erozijsko ogroženost smo določali z indeksom moči vodnega toka. V izseku Haloz je raba tal najbolj povezana z ekspozicijo površja, v izseku Slovenskih goric z nadmorsko višino površja, v vseh ostalih izsekih pa je najpomembnejša potencialna erozijska ogroženost.

KLJUČNE BESEDE: raba tal, relief, površje, digitalni model višin, nadmorska višina, naklon, ekspozicija, erozija, Slovenija.

Uredništvo je prejelo prispevek 18. maja 2006.

NASLOVI:

Mauro Hrvatin, univ. dipl. geogr.

Geografski inštitut Antona Melika

Znanstveoraziskovalni center Slovenske akademije znanosti in umetnosti

Gosposka ulica 13, SI - 1000 Ljubljana, Slovenija

E-pošta: mauro@zrc-sazu.si

Drago Perko, dr.

Geografski inštitut Antona Melika

Znanstveoraziskovalni center Slovenske akademije znanosti in umetnosti

Gosposka ulica 13, SI - 1000 Ljubljana, Slovenija

E-pošta:drago@zrc-sazu.si

Franci Petek, dr.

Geografski inštitut Antona Melika

Znanstveoraziskovalni center Slovenske akademije znanosti in umetnosti

Gosposka ulica 13, SI - 1000 Ljubljana, Slovenija

E-pošta: petek@zrc-sazu.si

\section{Vsebina}

1 Uvod 81

2 Izbrana območja $\quad 82$

3 Raba tal 83

$4 \quad$ Nadmorska višina površja $\quad 86$

$5 \quad$ Naklon površja $\quad 87$

6 Ekspozicija površja $\quad 88$

7 Potencialna erozijska ogroženost površja $\quad 89$

8 Sklep 90

9 Viri in literatura $\quad 91$ 


\section{Uvod}

Relief ali izoblikovanost površja med vsemi sestavinami pokrajine največ prispeva k zunanji podobi slovenskih pokrajin, raba tal, ki je močno odvisna od naravnih in družbenih sestavin pokrajine, pa je eden od najpomembnejših in najvidnejših pokazateljev naravnih in družbenih razmer v pokrajini. Ponekod je raba tal usklajena, povezana $\mathrm{z}$ reliefom, ponekod pa ne.

V članku analiziramo reliefne kazalce oziroma kazalce izoblikovanosti in potencialne erozijske ogroženosti površja glede na različne vrste rabe tal in ugotavljamo razlike med njimi, na tej podlagi pa določamo stopnjo povezanosti med reliefnimi kazalci in vrstami rabe tal oziroma vpliv reliefa na razlike v rabi tal, predvsem pa usklajenost rabe tal glede na potencialno erozijsko ogroženost površja.

Leta 2000 smo na Znanstvenoraziskovalnem centru Slovenske akademije znanosti in umetnosti iz radarskih slik, ki jih je European space agency»Evropska vesoljska agencija" posnela med letoma 1995 in 1999, za Geodetsko upravo Republike Slovenije izdelali petindvajsetmetrski digitalni model višin, tako imenovani interferometrični radarski digitalni model višin InSAR DMV 25 (Podobnikar, Oštir 1999; Oštir, Podobnikar, Stančič, Mlinar 2000; Podobnikar 2002). Sestavljajo ga podatki o nadmorskih višinah točk, ki so od severa proti jugu oziroma od vzhoda proti zahodu oddaljene $25 \mathrm{~m}$ in so oglišča kvadratnih celic $\mathrm{z}$ osnovnico $25 \mathrm{~m}$, diagonalo $35 \mathrm{~m}$ in površino $625 \mathrm{~m}^{2}$.

DMV 25 smo med letoma 2003 in 2005 z upoštevanjem obširnih zbirk podatkov o reliefu iz zadnjega desetletja 20. stoletja zgostili v DMV 12,5 (Podobnikar 2005). Sestavljajo ga podatki o nadmorskih višinah točk, ki so od severa proti jugu oziroma od vzhoda proti zahodu oddaljene $12,5 \mathrm{~m}$ in so oglišča kvadratnih celic z osnovnico $12,5 \mathrm{~m}$, diagonalo $17,7 \mathrm{~m}$ in površino $156,25 \mathrm{~m}^{2}$.

Testiranje je pokazalo, da je natančnost DMV 12,5 za celo Slovenijo 3,2 m, za ravnine 1,1 m, za gričevja 2,3 m, za hribovja 3,8 $\mathrm{m}$ in za gorovja 7,0 $\mathrm{m}$ (Podobnikar 2006, 25).

Od treh temeljnih geometričnih lastnosti ploskev, ki jih v okviru geografskega informacijskega sistema lahko ugotavljamo z digitalnim modelom višin, to so oddaljenost, nagnjenost in ukrivljenost glede na vodoravno in navpično ravnino (Perko 2002; Hrvatin in Perko 2002; Hrvatin in Perko 2003), smo za primerjavo izbrali tri lastnosti oziroma kazalce, ki se najpogosteje uporabljajo v geografiji. To so:

- nadmorska višina površja ali oddaljenost površja glede na vodoravno ravnino,

- naklon površja ali nagnjenost površja glede na vodoravno ravnino in

- ekspozicija površja ali nagnjenost površja glede na navpično ravnino.

Ugotovljeni kazalci pri DMV 12,5 slonijo na 153.600 podatkih za posamezna območja (slika 1), ki smo jih poimenovali po osrednjem naselju izbranih izsekov.

Nadmorske višine površja smo podali v metrih, naklone površja v stopinjah od 0 za ravno površje do 90 za navpično površje, ekspozicije površja pa v stopinjah od 0 za skrajno severno lego do 180 za skrajno južno lego. Izračunali smo jih za šest izsekov iz območij terciarnih gričevij v Sloveniji, ki so zaradi prevlade erozijsko slabo odpornih kamnin še posebej zanimiva. Med sredozemskimi gričevji smo izbrali Koprska brda, Brkine in Goriška brda, med celinskimi gričevji pa Haloze, Slovenske gorice in Goričko. Vsi pravokotni izseki imajo dolžino $6 \mathrm{~km}$, širino $4 \mathrm{~km}$ in površino $24 \mathrm{~km}^{2}$. Za računanje reliefnih kazalnikov ter povezovanje podatkovnih slojev reliefa, kamnin, rečne mreže in razvodnic smo uporabili programska paketa IDRISI (Eastman 1995) in ArcGIS (Shaner, Wrightsell 2000; Tucker 2000; McCoy, Johnston 2001).

Kot četrti reliefni kazalec smo dodali potencialno erozijsko ogroženost površja, ki smo jo ugotavljali s pomočjo indeksa moči vodnega toka (Lindsay 2005; Komac, Zorn 2005).

Indeks moči vodnega toka je mera denudacijsko-erozijskega potenciala vode, ki temelji na predpostavki, da se vodni pretok in denudacijsko-erozijska sposobnost vode večata sorazmerno z večanjem površine specifičnega izseka porečja. Indeks upošteva površino hidrološkega zaledja odseka izohipse, dolžino odseka izohipse in naklon površja na odseku izohipse. Pri uporabi digitalnega modela višin je površina hidrološkega zaledja odseka izohipse enaka površini hidrološkega zaledja kvadratne celice, dolžina odseka izohipse je enaka dolžini osnovnice kvadratne celice, naklon površja na odseku izohipse pa je enak naklonu kvadratne celice oziroma naklonu skupine kvadratnih celic.

Najmanjša vrednost indeksa moči vodnega toka, ko je površje na odseku izohipse oziroma v kvadratni celici ravno, je 0 . V tem primeru je tudi potencialna erozijska ogroženost enaka 0 . Večja je vrednost indeksa, večja je potencialna erozijska ogroženost.

Vrednosti indeksa smo za naše potrebe razdelili na štiri razrede in jih označili: 
- neznatna erozija (vrednosti indeksa med 0 in 9),

- šibka erozija (vrednosti indeksa med 10 in 99),

- zmerna erozija (vrednosti indeksa med 100 in 999),

- močna erozija (vrednosti indeksa med 1000 in več).

Slika 1: Na skici izračuna indeksa moči vodnega toka sta prikazana dva primera v porečju Suhega potoka v Posavskem hribovju (porečje omejejuje rdeča črta), pri čemer A pomeni površino hidrološkega zaledja odseka izohipse, b dolžino odseka izohipse in $\alpha$ naklon površja na odseku izohipse. Indeks moči vodnega toka $I_{\text {MVT }}=(A: b) \cdot \tan \alpha$. V prvem primeru je indeks moči vodnega toka $2143 \mathrm{~m}^{2} / \mathrm{m}$ $\left.\left(I_{M V T}=\left(245.000 \mathrm{~m}^{2}: 10 \mathrm{~m}\right) \cdot \tan 5^{\circ}\right)\right)$, v drugem primeru pa $\left.94 \mathrm{~m}^{2} / \mathrm{m}\left(\mathrm{I}_{\mathrm{MVT}}=\left(29.580 \mathrm{~m}^{2}: 160 \mathrm{~m}\right) \cdot \tan 27^{\circ}\right)\right)$.

Glej angleški del prispevka.

Povezanost med oblikovanostjo in potencialno erozijsko ogroženostjo površja ter rabo tal smo ugotavljali: - opisno z razporeditvijo posameznih vrst rabe tal po razredih nadmorske višine, naklona, ekspozicije in potencialne erozijske ogroženosti površja,

- računsko s Hirschmanovim koeficientom koncentracije $c c$ (Blejec 1976; Perko 2001), ki temelji na deležih posameznih vrst rabe tal po razredih določenega reliefnega kazalca in ima vrednosti med 0, ko je določena vrsta rabe tal enakomerno porazdeljena po razredih, in 1 , ko je osredotočena, zgoščena le v enem razredu (večji je koeficient koncentracije, večja je zgoščenost posamezne vrste rabe tal in večja možnost, da zgoščenost ni slučajna, ampak odvisna od upoštevanega reliefnega kazalca),

- računsko s koeficientom kontingenčne korelacije $\boldsymbol{r}$ (Blejec 1976; Perko 2001), ki temelji na $h i^{2}$ oziroma pogostnosti pojavljanja vseh vrst rabe tal po vseh razredih kontingenčne tabele določenega reliefnega kazalca.

Vse izračunane vrednosti $h i^{2}$ in koeficienta korelacije bistveno presegajo vrednost mejnega $h i^{2}$ in mejnega koeficienta korelacije za statistično pomembnost pri 99,9\% zaupanju, kar pomeni, da z 0,1\% tveganjem lahko sklepamo, da so višina, naklon, ekspozicija in potencialna erozijska ogroženost površja statistično pomembno povezani z vrstami rabe tal.

\section{Izbrana območja}

Odločili smo se za šest območij terciarnih gričevij. Med sredozemskimi gričevji smo izbrali Koprska brda, Brkine in Goriška brda, med celinskimi gričevji pa Haloze, Slovenske gorice in Goričko (slika 2).

V Koprskih brdih (slika 3) smo izbrali izsek na jugovzhodu okrog naselja Bočaji, ki obsega flišni gričevnati svet v povirju Dragonje z višinskim razmikom med 82 in $415 \mathrm{~m}$, povprečnim naklonom 13,2 $2^{\circ}$, povprečno ekspozicijo $99,9^{\circ}$ in povprečno vrednostjo indeksa moči vodnih tokov $70,8 \mathrm{~m}^{2} / \mathrm{m}$. Prevladujejo redka gručasta naselja, med katerimi so večje le Marezige.

V Brkinih (slika 4) smo izbrali izsek na osrednjem flišnem slemenu okrog naselja Pregarje z višinskim razmikom med 437 in $771 \mathrm{~m}$, povprečnim naklonom $16,2^{\circ}$, povprečno ekspozicijo $94,1^{\circ}$ in povprečno vrednostjo indeksa moči vodnih tokov $64,6 \mathrm{~m}^{2} / \mathrm{m}$. Značilna so redka in manjša strnjena naselja, ki so ponekod razpotegnjena vzdolž slemen.

V Goriških brdih (slika 5) smo izbrali izsek v flišnem osredju okrog naselja Imenje z višinskim razmikom med 77 in $426 \mathrm{~m}$, povprečnim naklonom $16,5^{\circ}$, povprečno ekspozicijo $99,0^{\circ}$ in povprečno vrednostjo indeksa moči vodnih tokov $66,6 \mathrm{~m}^{2} / \mathrm{m}$. Značilna so številna gručasta naselja, med njimi so večja Dobrovo, Kozana, Kojsko, Hum in Šmartno.

V zahodnem, gozdnatem delu Haloz (slika 6) smo izbrali izsek v lapornem osredju okrog naselja Kočice $\mathrm{z}$ višinskim razmikom med 253 in $512 \mathrm{~m}$, povprečnim naklonom $21,7^{\circ}$, povprečno ekspozicijo $92,3^{\circ}$ in povprečno vrednostjo indeksa moči vodnih tokov $59,3 \mathrm{~m}^{2} / \mathrm{m}$. Značilna so redka, močno razložena naselja s številnimi zaselki, ki so raztreseni daleč naokoli.

V Slovenskih goricah (slika 7) smo izbrali izsek na peščenem in prodnatem svetu okrog naselja Pršetinci Z višinskim razmikom med 213 in $326 \mathrm{~m}$, povprečnim naklonom $8,2^{\circ}$, povprečno ekspozicijo $96,4^{\circ}$ in povprečno vrednostjo indeksa moči vodnih tokov $22,3 \mathrm{~m}^{2} / \mathrm{m}$. Značilna je gosta mreža manjših razloženih naselij.

$\mathrm{Na}$ Goričkem (slika 8) smo izbrali izsek na prodnatem in ilovnatem svetu okrog naselja Markovci Z višinskim razmikom med 246 in $352 \mathrm{~m}$, povprečnim naklonom $6,6^{\circ}$, povprečno ekspozicijo $105,2^{\circ}$ in povprečno vrednostjo indeksa moči vodnih tokov $18,7 \mathrm{~m}^{2} / \mathrm{m}$. Značilna so redka razložena naselja.

Slika 2: Lega izbranih območij na poenostavljenem stratigrafskem zemljevidu Slovenije.

Glej angleški del prispevka. 
Slika 3: Območje v okolici Bočajev, Koprska brda (fotografija: Matevž Lenarčič).

Glej angleški del prispevka.

Slika 4: Območje v okolici Pregarij, Brkini (fotografija: Matevž Lenarčič).

Glej angleški del prispevka.

Slika 5: Območje v okolici Imenj, Goriška brda (fotografija: Matevž Lenarčič).

Glej angleški del prispevka.

Slika 6: Območje v okolici Kočic, Haloze (fotografija: Matevž Lenarčič).

Glej angleški del prispevka.

Slika 7: Območje v okolici Pršetincev, Slovenske gorice (fotografija: Matevž Lenarčič).

Glej angleški del prispevka.

Slika 8: Območje v okolici Markovcev, Goričko (fotografija: Matevž Lenarčič).

Glej angleški del prispevka.

Preglednica 1: Nekateri statistični kazalci za nadmorsko višino, naklon, ekspozicijo in potencialno erozijsko ogroženost površja po posameznih območjih.

\begin{tabular}{|c|c|c|c|c|c|c|}
\hline & $\begin{array}{c}\text { Bočaji } \\
\text { (Koprska brda) }\end{array}$ & $\begin{array}{l}\text { Pregarje } \\
\text { (Brkini) }\end{array}$ & $\begin{array}{c}\text { Imenje } \\
\text { (Goriška brda) }\end{array}$ & $\begin{array}{l}\text { Kočice } \\
\text { (Haloze) }\end{array}$ & $\begin{array}{c}\text { Pršetinci } \\
\text { (Slovenske gorice) }\end{array}$ & $\begin{array}{l}\text { Markovci } \\
\text { (Goričko) }\end{array}$ \\
\hline \multicolumn{7}{|l|}{ višina } \\
\hline nižek & 82,0 & 437,0 & 77,0 & 253,0 & 213,0 & 246,0 \\
\hline višek & 415,0 & 771,0 & 426,0 & 512,0 & 326,0 & 352,0 \\
\hline razmik & 333,0 & 334,0 & 349,0 & 259,0 & 113,0 & 106,0 \\
\hline povprečje & 272,8 & 603,1 & 186,0 & 348,1 & 264,9 & 297,8 \\
\hline standardni odklon & 56,9 & 70,5 & 73,0 & 42,6 & 21,1 & 21,8 \\
\hline \multicolumn{7}{|l|}{ naklon } \\
\hline nižek & 0,0 & 0,0 & 0,0 & 0,0 & 0,0 & 0,0 \\
\hline višek & 45,0 & 43,9 & 47,7 & 54,0 & 31,9 & 24,5 \\
\hline razmik & 45,0 & 43,9 & 47,7 & 54,0 & 31,9 & 24,5 \\
\hline povprečje & 13,2 & 16,2 & 16,5 & 21,7 & 8,2 & 6,6 \\
\hline standardni odklon & 6,9 & 7,2 & 8,0 & 9,5 & 5,0 & 3,6 \\
\hline \multicolumn{7}{|l|}{ ekspozicija } \\
\hline nižek & 0,0 & 0,0 & 0,0 & 0,0 & 0,0 & 0,0 \\
\hline višek & 180,0 & 180,0 & 180,0 & 180,0 & 180,0 & 180,0 \\
\hline razmik & 180,0 & 180,0 & 180,0 & 180,0 & 180,0 & 180,0 \\
\hline povprečje & 99,9 & 94,1 & 99,0 & 92,3 & 96,4 & 105,2 \\
\hline standardni odklon & 57,5 & 50,3 & 51,6 & 51,8 & 53,8 & 50,8 \\
\hline \multicolumn{7}{|c|}{$\begin{array}{l}\text { indeks relativne moči } \\
\text { vodnih tokov }\end{array}$} \\
\hline nižek & 0,0 & 0,0 & 0,0 & 0,0 & 0,0 & 0,0 \\
\hline višek & 10979 & 7975 & 7253 & 5636 & 890 & 1119 \\
\hline razmik & 10979 & 7975 & 7253 & 5636 & 890 & 1119 \\
\hline povprečje & 70,8 & 64,6 & 66,6 & 59,3 & 22,3 & 18,7 \\
\hline standardni odklon & 189,3 & 141,3 & 169,0 & 103,6 & 35,2 & 26,3 \\
\hline
\end{tabular}

\section{Raba tal}

S pojmom raba tal izražamo predvsem namembnost površin oziroma zemljišč v pokrajini za gospodarske in druge dejavnosti. Med geografskimi panogami se z rabo tal največ ukvarjata agrarna geografija (Gabrovec in Kladnik 1997; Kladnik in Gabrovec 1998, Gabrovec, Kladnik in Petek 2001; Petek 2002; Hrvatin in Perko 2003; Petek 2005a; Petek 2005b) in geografija podeželja (Urbanc 2002; Kladnik in Ravbar 2003; Topole 2003). 
Površine ali zemljišča z enako rabo tal imenujemo zemljiška kategorija ali vrsta rabe tal. Temeljni vir za preučevanje rabe tal so podatki zemljiškega katastra, ki ga v Sloveniji po katastrskih občinah vodi Geodetska uprava Republike Slovenije. Katastrske občine so temeljne teritorialne enote za vodenje zemljiškega katastra. V Sloveniji jih je 2698. Zaradi počasnega vnašanja sprememb v kataster podatki zaostajajo za dejanskimi razmerami v pokrajini.

Med najstarejšimi uradnimi popisi zemljišč na ozemlju današnje Slovenije je najbolj popoln tako imenovani franciscejski ali stabilni kataster iz prve polovice 19. stoletja. Razlikoval je pet temeljnih zemljiških kategorij oziroma vrst rabe tal (polje, travnik, pašnik, gozd in vinograd), ob njih pa še zemljišča z mešano rabo (na primer travnik s sadnim drevjem) in zemljišča s posebno rabo (na primer hmeljišče, močvirje, kamnolom).

Med najnovejšimi podatkovnimi zbirkami dejansko rabo tal zajemajo različni zemljevidi, izdelani s pomočjo daljinskega zaznavanja. Za naše delo je med njimi najbolj zanesljiv in uporaben digitalni zemljevid vrst rabe tal Raba kmetijskih zemljišč, ki je bil v svoji prvi različici izdan leta 2002 (Raba kmetijskih zemljišč, različica 1.0_2002). Nastal je v okviru Projekta posodobitve evidentiranja nepremičnin oziroma njegovega podprojekta Zajem in spremljanje rabe kmetijskih zemljišč, pri katerem so sodelovali Ministrstvo za kmetijstvo, gozdarstvo in prehrano, Geodetska uprava Republike Slovenije, Vrhovno sodišče Republike Slovenije, Ministrstvo za finance ter Ministrstvo za pravosodje. Digitalni zemljevid spremlja podatkovna zbirka, ki povezuje register kmetij, zemljiški kataster in zemljiško knjigo. Vzpostavljena je bila zaradi določanja višine subvencij na površino kmetij (Lipej 2001).

Vir podatkov za zemljevid so digitalni ortofoto načrti v merilu $1: 5000$, ki temeljijo na črno-belih letalskih posnetkih v merilu $1: 17.500$ in terenskem preverjanju. Podprojekt se je začel leta 1998, ko so na 50 vzorčnih listih interpretirali vrste rabe tal, na tej podlagi določili interpretacijski ključ in vektorsko omejili vsako vrsto rabe tal. Delo so končali leta $2002 \mathrm{z}$ združitvijo vseh digitalnih ortofoto načrtov v enoten zemljevid (Rotter 2001). Njegova slabost je prav neenoten čas zajema (fotografiranja) podatkov po različnih območjih Slovenije. Zato je bila že opravljena revizija rabe na približno tretjini ozemlja Slovenija (Dejanska raba kmetijskih zemljišč, različica Raba_beta_20050408). To zadnjo različico smo uporabili pri naših analizah.

$\mathrm{Na}$ zemljevidu je 22 različnih vrst rabe tal:

- njive in vrtovi,

- začasni travniki,

- hmeljišča,

- vinogradi,

- intenzivni sadovnjaki,

- ekstenzivni sadovnjaki,

- oljčni nasadi,

- ostali trajni nasadi,

- trajni travniki in pašniki,

- barjanski travniki,

- zemljišča v zaraščanju,

- plantaže gozdnega drevja,

- drevesa in grmičevje,

- kmetijske površine porasle z gozdnim drevjem,

- gozd,

- pozidana in sorodna zemljišča,

- barja,

- trstičja,

- ostala zamočvirjena zemljišča,

- suha odprta zemljišča s posebnim rastlinskim pokrovom,

- odprta zemljišča brez ali z nepomembnim rastlinskim pokrovom,

- vode.

Za našo raziskavo smo teh 22 temeljnih vrst rabe tal smiselno združili v 7 skupin vrst rabe tal:

- njive (v skupino smo uvrstili njive in vrtove, začasne travnike ter hmeljišča),

- vinogradi in drugi sorodni trajni nasadi (v skupino smo uvrstili vinograde, oljčnike ter ostale trajne nasade),

- sadovnjaki (v skupino smo uvrstili intenzivne sadovnjake ter ekstenzivne sadovnjake),

- travniki in pašniki ( $\mathrm{v}$ skupino smo uvrstili trajne travnike in pašnike ter barjanske travnike), 
- gozdovi (v skupino smo uvrstili zemljišča v zaraščanju, plantaže gozdnega drevja, drevesa in grmičevje, kmetijske površine porasle z gozdnim drevjem ter gozd),

- pozidane površine (v skupino smo uvrstili pozidana in sorodna zemljišča),

- ostale vrste rabe tal (v skupino smo uvrstili barja, trstičja, ostala zamočvirjena zemljišča, suha odprta zemljišča s posebnim pokrovom, odprta zemljišča brez ali z nepomembnim rastlinskim pokrovom ter vode).

Na temelju takšnega združevanja smo iz zemljevida temeljnih vrst rabe tal pripravili zemljevid skupin vrst rabe tal in ga kot nov sloj prenesli v geografski informacijski sistem ter povezali z digitalnim modelom višin.

V nadaljnjem besedilu namesto izraza skupine vrst rabe tal uporabljamo kar poenostavljeni izraz vrste rabe tal.

Izbrani izseki v terciarnih gričevjih se po rabi tal med seboj razlikujejo močneje kot po reliefnih in drugih naravnih značilnostih, saj poleg kamninske podlage in reliefa na rabo tal vplivajo tudi drugi naravni in družbeni dejavniki. To potrjujejo primerjava deležev vrst rabe med izbranimi območji. Njiv je v izseku Goričkega kar tretjina celotne površine, v Goriških brdih pa manj kot odstotek. Ravno obratno je razmerje pri vinogradih. Izsek Goriških brd izstopa po največjem deležu sadovnjakov, v izseku Koprskih brdih pa sadovnjakov skoraj ni. Izsek Haloz ima skoraj še enkrat toliko travnikov in pašnikov kot ostali izseki, z izjemo izjemo izseka Goriških brd, kjer je te zemljiške kategorije še najmanj. Po gozdnatosti izstopa izsek Brkinov, kjer gozdovi poraščajo skoraj štiri petine vsega površja, najmanjši delež gozda pa je v izseku Slovenskih goricah, a je še vedno večji od dveh petin. V vseh izsekih prevladujejo gozdovi, kot druga vrsta rabe tal pa v izseku Koprskih brd, Brkinov in Haloz sledijo travniki, v izseku Goriških brd vinogradi, v izseku Slovenskih goric in Goričkega pa njive. V vseh sredozemskih izsekih skupaj so na prvem mestu gozdovi in na drugem mestu vinogradi, $\mathrm{v}$ vseh celinskih izsekih skupaj pa na prvem mestu gozdovi in na drugem mestu njive. Če upoštevamo vsa slovenska sredozemska gričevja skupaj, so na prvem mestu gozdovi in nato travniki, enako pa velja tudi za vsa slovenska celinska gričevja skupaj (preglednica 2).

Preglednica 2: Združene vrste rabe tal po izbranih območjih terciarnih gričevij.

\begin{tabular}{|c|c|c|c|c|c|c|c|}
\hline & njive & vinogradi & sadovnjaki & travniki & gozd & ostalo & skupaj \\
\hline \multicolumn{8}{|l|}{ vha } \\
\hline Bočaji (Koprska brda) & 8421 & 10655 & 209 & 26691 & 102439 & 5185 & 153600 \\
\hline Pregarje (Brkini) & 2306 & 102 & 5519 & 22755 & 120090 & 2828 & 153600 \\
\hline Imenje (Goriška brda) & 1045 & 51175 & 17038 & 10784 & 63932 & 9626 & 153600 \\
\hline Kočice (Haloze) & 6447 & 4079 & 6562 & 44550 & 85920 & 6042 & 153600 \\
\hline Pršetinci (Slovenske gorice) & 39335 & 7785 & 5341 & 27055 & 63250 & 10834 & 153600 \\
\hline Markovci (Goričko) & 50814 & 537 & 3196 & 24194 & 68726 & 6133 & 153600 \\
\hline \multicolumn{8}{|l|}{$\mathrm{V} \%$} \\
\hline Bočaji (Koprska brda) & 5,48 & 6,94 & 0,14 & 17,38 & 66,69 & 3,38 & 100,00 \\
\hline Pregarje (Brkini) & 1,50 & 0,07 & 3,59 & 14,81 & 78,18 & 1,84 & 100,00 \\
\hline Imenje (Goriška brda) & 0,68 & 33,32 & 11,09 & 7,02 & 41,62 & 6,27 & 100,00 \\
\hline Kočice (Haloze) & 4,20 & 2,66 & 4,27 & 29,00 & 55,94 & 3,93 & 100,00 \\
\hline Pršetinci (Slovenske gorice) & 25,61 & 5,07 & 3,48 & 17,61 & 41,18 & 7,05 & 100,00 \\
\hline Markovci (Goričko) & 33,08 & 0,35 & 2,08 & 15,75 & 44,74 & 3,99 & 100,00 \\
\hline sredozemski izseki skupaj & 2,55 & 13,44 & 4,94 & 13,07 & 62,17 & 3,83 & 100,00 \\
\hline panonski izseki skupaj & 20,96 & 2,69 & 3,28 & 20,79 & 47,29 & 4,99 & 100,00 \\
\hline sredozemska gričevja skupaj & 7,96 & 6,8 & 3,56 & 18,18 & 55,45 & 8,05 & 100,00 \\
\hline panonska gričevja skupaj & 21,77 & 4,17 & 2,94 & 21,99 & 41,56 & 7,57 & 100,00 \\
\hline
\end{tabular}

Slika 9: Raba tal območja v okolici Bočajev, Koprska brda.

Glej angleški del prispevka.

Slika 10: Raba tal območja v okolici Pregarij, Brkini.

Glej angleški del prispevka.

Slika 11: Raba tal območja v okolici Imenj, Goriška brda.

Glej angleški del prispevka. 
Slika 12: Raba tal območja v okolici Kočic, Haloze.

Glej angleški del prispevka.

Slika 13: Raba tal območja v okolici Pršetincev, Slovenske gorice.

Glej angleški del prispevka.

Slika 14: Raba tal območja v okolici Markovcev, Goričko.

Glej angleški del prispevka.

Legenda za slike od 9 do 14: njive - rjava, vinogradi - vijolična, sadovnjaki - rumena, travniki in pašniki - svetlo zelena, gozd - temno zelena, pozidane površine - rdeča, ostale površine - modra.

\section{Nadmorska višina površja}

Če upoštevamo temeljne vrste rabe tal, torej njive, vinograde, sadovnjake, travnike in gozdove, ter vse izseke skupaj, so glede na višinske pasove najbolj zgoščeni vinogradi s povprečnim koeficientom koncentracije 0,5605 , nato sadovnjaki s koeficientom 0,4944 , na sredini so gozdovi s koeficientom 0,4445 , na koncu pa njive s koeficientom 0,4286 in travniki s koeficientom 0,3896 .

V izseku Goriških brd so glede na petdesetmetrske višinske pasove najbolj zgoščene njive, saj jih kar štiri petine leži v višinskih pasovih med 50 in $150 \mathrm{~m}$, ki pomenijo manj kot dve petini vseh površin. Najbolj enakomerno so razporejeni travniki.

V izseku Koprskih brd so najbolj zgoščeni sadovnjaki, saj jih kar dve tretjini leži v višinskih pasovih med 300 in $400 \mathrm{~m}$, ki pomenijo komaj tretjino vseh površin. Najbolj enakomerno so razporejene njive.

V izseku Brkinov so najbolj zgoščeni vinogradi, V višinskem pasu med 600 in 650 m, ki pomeni petino vseh površin, so kar tri petine vseh vinogradov. Najbolj enakomerno so razporejene njive.

Tudi v izseku Haloz so najbolj zgoščeni vinogradi, saj jih kar devet desetin leži v višinskih pasovih med 350 in $450 \mathrm{~m}$, ki pomenijo manj kot polovico vseh površin. Najbolj enakomerno so razporejeni travniki, katerih delež je po višinskih pasovih skoraj povsem enak deležu površin istih višinskih pasov.

Tretje območje, kjer so najbolj zgoščeni vinogradi, je izsek Goričkega. Štiri petine jih leži v višinskem pasu med 300 in 350 m, ki pomeni manj kot polovico vseh površin. Najbolj enakomerno so razporejeni gozdovi.

V izseku Slovenskih goric so najbolj zgoščeni sadovnjaki. Kar štiri petine sadovnjakov je v višinskem pasu med 250 in $300 \mathrm{~m}$. Najbolj enakomerno so razporejene njive.

Poleg razporeditve vrst rabe tal po višinskih pasovih je zanimiva tudi gostota posamezne vrste rabe tal v posameznih višinskih pasovih.

V izseku Koprskih brd dosegajo največjo gostoto gozdovi, ki poraščajo ves višinski pas med 50 in 100 m, tako da je njihova gostota 100 ha na $\mathrm{km}^{2}$, v izseku Goriških brd gozdovi v višinskem pasu med 300 in $350 \mathrm{~m}$ z gostoto 69 ha na km², v izseku Brkinov gozdovi v višinskem pasu med 450 in 499 z gostoto 87 ha na km², v izseku Haloz gozdovi v višinskem pasu med 300 in $350 \mathrm{~m} \mathrm{z}$ gostoto 62 ha na $\mathrm{km}^{2}$ in tudi v izseku Slovenskih goric gozdovi v višinskem pasu med 250 in $300 \mathrm{~m}$ z gostoto $47 \mathrm{ha} \mathrm{na} \mathrm{km²}$, v izseku Goričkega pa njive $\mathrm{v}$ višinskem pasu med 200 in $250 \mathrm{~m} \mathrm{z}$ gostoto 54 ha na $\mathrm{km}^{2}$.

To je tudi največja gostota njiv v vseh izsekih. Vinogradi imajo največjo gostoto v izseku Goriških brd $\mathrm{v}$ višinskem pasu med 100 in $150 \mathrm{~m}$ z gostoto 43 ha na $\mathrm{km}^{2}$, sadovnjaki prav tako v izseku Goriških brd $\mathrm{v}$ višinskem pasu med 50 in $100 \mathrm{~m}$ z gostoto 19 ha na $\mathrm{km}^{2}$, travniki v izseku Brkinov v višinskem pasu med 750 in $800 \mathrm{~m}$ z gostoto 50 ha na km², gozdovi pa, kot rečeno, v izseku Koprskih brd v višinskem pasu med 50 in $100 \mathrm{~m}$ z gostoto 100 ha na $\mathrm{km}^{2}$

Slika 15: Višine območja v okolici Bočajev, Koprska brda.

Glej angleški del prispevka.

Slika 16: Višine območja v okolici Pregarij, Brkini.

Glej angleški del prispevka.

Slika 17: Višine območja v okolici Imenj, Goriška brda.

Glej angleški del prispevka. 
Slika 18: Višine območja v okolici Kočic, Haloze.

Glej angleški del prispevka.

Slika 19: Višine območja v okolici Pršetincev, Slovenske gorice.

Glej angleški del prispevka.

Slika 20: Višine območja v okolici Markovcev, Goričko.

Glej angleški del prispevka.

Legenda za slike od 15 do 20: od $0 \mathrm{~m}$ do $199 \mathrm{~m}$ - odtenki zelene, od $200 \mathrm{~m}$ do $399 \mathrm{~m}$ - odtenki rumene, od $400 \mathrm{~m}$ do $599 \mathrm{~m}$ - odtenki oranžne, od $600 \mathrm{~m}$ do $800 \mathrm{~m}$ - odtenki rdeče.

\section{Naklon površja}

Če upoštevamo vse izseke skupaj, so glede na naklonske razrede najbolj zgoščeni sadovnjaki s povprečnim koeficientom koncentracije 0,4913 , nato vinogradi s koeficientom 0,4852 , na sredini so gozdovi s koeficientom 0,4384 , na koncu pa njive s koeficientom 0,4380 in travniki s koeficientom 0,4184 . Razlike med koeficienti so manjše kot pri višinskih pasovih.

V izseku Goriških brd so glede na naklonske razrede najbolj zgoščeni gozdovi, saj jih skoraj štiri petine leži v naklonskih razredih pod $6^{\circ}$, ki pomenijo komaj desetino vseh površin. Najbolj enakomerno so razporejeni travniki.

V izseku Koprskih brd so najbolj zgoščene njive, saj jih kar devet desetin leži v naklonskih razredih med 2 in $12^{\circ}$, ki pomenijo manj kot polovico vseh površin. Najbolj enakomerno so razporejeni gozdovi.

V izseku Brkinov so najbolj zgoščeni vinogradi. V naklonskih razredih med 2 in $12^{\circ}$ jih leži štiri petine, čeprav ti razredi pokrivajo manj kot tretjino površin. Najbolj enakomerno so razporejeni gozdovi.

V izseku Haloz so najbolj zgoščeni sadovnjaki, saj jih kar štiri petine leži v naklonskih razredih med 12 in $30^{\circ}$, ki pomenijo manj kot tretjino vseh površin. Najbolj enakomerno so razporejene njive.

Tudi v izseku Slovenskih goric so najbolj zgoščeni sadovnjaki. Tri četrtine sadovnjakov je v naklonskih razredih med 6 in $30^{\circ}$. Najbolj enakomerno so razporejeni travniki.

Tretje območje, kjer so najbolj zgoščeni sadovnjaki, je izsek Goričkega. Več kot devet desetin sadovnjakov leži v naklonskih razredih med 2 in $12^{\circ}$. Najbolj enakomerno so razporejene njive.

Poleg razporeditve vrst rabe tal po naklonskih razredih je zanimiva tudi gostota posamezne vrste rabe tal v posameznih naklonskih razredih.

$\mathrm{V}$ vseh izsekih dosegajo največjo gostoto gozdovi, in sicer v izseku Koprskih brd v naklonskem razredu nad $30^{\circ} \mathrm{z}$ gostoto 98 ha na $\mathrm{km}^{2}$, v izseku Goriških brd $\mathrm{v}$ istem razredu z gostoto 90 ha na $\mathrm{km}^{2}$, v izseku Brkinov v istem razredu $\mathrm{z}$ gostoto kar 100 ha na $\mathrm{km}^{2}$ in $\mathrm{v}$ izseku Haloz $\mathrm{v}$ istem razredu $\mathrm{z}$ gostoto 80 ha na $\mathrm{km}^{2}$, v izseku Slovenskih goric pa v naklonskem razredu med 20 in $30^{\circ} \mathrm{z}$ gostoto 71 ha na $\mathrm{km}^{2}$ in v izse$\mathrm{ku}$ Goričkega prav tako v naklonskem razredu med 20 in $30^{\circ} \mathrm{z}$ gostoto 85 ha na $\mathrm{km}^{2}$.

Njive imajo največjo gostoto $\mathrm{v}$ izseku Goričkega $\mathrm{v}$ naklonskem razredu pod $2^{\circ} \mathrm{z}$ gostoto $56 \mathrm{ha} \mathrm{na} \mathrm{km}^{2}$, vinogradi imajo največjo gostoto v izseku Goriških brd v naklonskem razredu med 6 in $12^{\circ} \mathrm{z}$ gostoto 44 ha na $\mathrm{km}^{2}$, sadovnjaki prav tako $\mathrm{v}$ izseku Goriških brd $\mathrm{v}$ naklonskem razredu pod $2^{\circ} \mathrm{z}$ gostoto 20 ha na $\mathrm{km}^{2}$, travniki v izseku Brkinov v naklonskem razredu pod $2^{\circ} \mathrm{z}$ gostoto $36 \mathrm{ha} \mathrm{na} \mathrm{km}^{2}$, gozdovi pa prav tako, kot rečeno, v izseku Brkinov v naklonskem razredu nad $30^{\circ} \mathrm{z}$ gostoto 100 ha na $\mathrm{km}^{2}$.

Slika 21: Nakloni območja v okolici Bočajev, Koprska brda.

Glej angleški del prispevka.

Slika 22: Nakloni območja v okolici Pregarij, Brkini.

Glej angleški del prispevka.

Slika 23: Nakloni območja v okolici Imenj, Goriška brda.

Glej angleški del prispevka.

Slika 24: Nakloni območja v okolici Kočic, Haloze.

Glej angleški del prispevka. 
Slika 25: Nakloni območja v okolici Pršetincev, Slovenske gorice.

Glej angleški del prispevka.

Slika 26: Nakloni območja v okolici Markovcev, Goričko.

Glej angleški del prispevka.

Legenda za slike od 21 do 26: od $0^{\circ}$ do $2^{\circ}$ - temno zelena, od $2^{\circ}$ do $6^{\circ}$ - svetlo zelena, od $7^{\circ}$ do $12^{\circ}$ - rumena, od $13^{\circ}$ do $20^{\circ}$ - svetlo rdeča in od $21^{\circ}$ navzgor - temno rdeča.

\section{Ekspozicija površja}

Če upoštevamo vse izseke skupaj, so glede na ekspozicijske razrede najbolj zgoščeni vinogradi s povprečnim koeficientom koncentracije 0,4755 , nato njive s koeficientom 0,3001 , sledijo sadovnjaki s koeficientom 0,2219 , na koncu pa travniki s koeficientom 0,2042 in gozdovi s koeficientom komaj 0,1001. Izstopajo vinogradi. Razmerje med koeficientom za vinograde in gozdove je pri ekspozicijah površja skoraj $5: 1$, pri naklonih površja pa sta koeficienta skoraj enaka.

V izseku Goriških brd so glede na ekspozicijske razrede najbolj zgoščene njive, najbolj enakomerno pa so razporejeni gozdovi. V izseku Koprskih brd, Brkinov, Haloz in Goričkega so najbolj zgoščeni vinogradi in najmanj gozdovi, v izseku Slovenskih goric pa najbolj vinogradi in najmanj sadovnjaki.

Poleg razporeditve vrst rabe tal po ekspozicijskih razredih je zanimiva tudi gostota posamezne vrste rabe tal v posameznih ekspozicijskih razredih.

$\mathrm{V}$ vseh izsekih dosegajo največjo gostoto gozdovi na severnih legah, in sicer v izseku Koprskih brd z gostoto 79 ha na km², v izseku Goriških brd z gostoto 49 ha na $\mathrm{km}^{2}$, v izseku Brkinov z gostoto 82 ha na $\mathrm{km}^{2}$, v izseku Haloz z gostoto 77 ha na $\mathrm{km}^{2}$ in v izseku Slovenskih goric z gostoto 51 ha na km², le v izseku Goričkega gozdovi na vzhodnih in zahodnih legah z gostoto 49 ha na $\mathrm{km}^{2}$.

Njive imajo največjo gostoto v izseku Goričkega na južnih legah z gostoto $37 \mathrm{ha} \mathrm{na} \mathrm{km}^{2}$, vinogradi imajo največjo gostoto v izseku Goriških brd na vzhodnih in zahodnih legah z gostoto 36 ha na $\mathrm{km}^{2}$, sadovnjaki prav tako v izseku Goriških brd na južnih legah z gostoto 13 ha na $\mathrm{km}^{2}$, travniki v izseku Haloz na južnih legah z gostoto 41 ha na km², gozdovi pa, kot rečeno, v izseku Brkinov na severnih legah z gostoto $82 \mathrm{ha} \mathrm{na} \mathrm{km².}$

Zanimivo je tudi spreminjanje gostote posameznih ekspozicijskih razredov po posameznih vrstah rabe tal. Gostota površin s severnimi legami je v vseh izsekih največja pri gozdovih, na primer v izseku Haloz kar 43 ha severnih leg na $\mathrm{km}^{2}$ gozdov. Najmanjša je v vseh izsekih pri vinogradih, na primer v izseku Brkinov le 1 ha severnih leg na $\mathrm{km}^{2}$ vinogradov, razen pri izseku Goričkega, kjer je to pri njivah.

Gostota površin z južnimi legami je v izsekih Koprskih brd, Haloz, Goričkega in Slovenskih goric največja pri vinogradih, na primer v izseku Koprskih brd kar 76 ha južnih leg na km² vinogradov, v izseku Goriških brd je največja pri njivah s 53 ha južnih leg na $\mathrm{km}^{2}$ njiv, v izseku Brkinov pa pri sadovnjakih s 46 ha južnih leg na $\mathrm{km}^{2}$ sadovnjakov. Najmanjša je v vseh izsekih pri gozdovih, na primer v izseku Haloz le 21 ha južnih leg na km² gozdov, razen v izseku Brkinov, kjer je presenetljivo pri vinogradih s komaj 14 ha južnih leg na $1 \mathrm{~km}^{2}$ vinogradov.

Slika 27: Ekspozicije območja v okolici Bočajev, Koprska brda.

Glej angleški del prispevka.

Slika 28: Ekspozicije območja v okolici Pregarij, Brkini.

Glej angleški del prispevka.

Slika 29: Ekspozicije območja v okolici Imenj, Goriška brda.

Glej angleški del prispevka.

Slika 30: Ekspozicije območja v okolici Kočic, Haloze.

Glej angleški del prispevka.

Slika 31: Ekspozicije območja v okolici Pršetincev, Slovenske gorice.

Glej angleški del prispevka. 
Slika 32: Ekspozicije območja v okolici Markovcev, Goričko.

Glej angleški del prispevka.

Legenda za slike od 27 do 32: severne lege - vijolična, vzhodne in zahodne lege - oranžna, južne lege - rumena.

\section{Potencialna erozijska ogroženost površja}

Če upoštevamo vse izseke skupaj, so glede na erozijske razrede najbolj zgoščeni vinogradi s povprečnim koeficientom koncentracije 0,6619 , nato gozdovi s koeficientom 0,6388 , sledijo sadovnjaki s koeficientom 0,6051 , na koncu pa travniki s koeficientom 0,5976 in njive s koeficientom 0,5651. Koeficienti so si podobni, v primerjavi s koeficienti pri višini, naklonu in ekspoziciji površja pa so zelo visoki.

V izseku Goriških brd so najbolj zgoščeni vinogradi, saj jih skoraj tri četrtine leži v razredu šibke erozije, najbolj enakomerno pa so razporejene njive.

Tudi v izseku Koprskih brd so najbolj zgoščeni vinogradi, saj jih skoraj tri četrtine leži v razredu šibke erozije, najbolj enakomerno pa so razporejeni sadovnjaki.

Tretje območje, kjer so najbolj zgoščeni vinogradi, je izsek Brkinov. Skoraj devet desetin vinogradov je v razredu šibke erozije. Najbolj enakomerno so razporejeni travniki.

Tudi v izseku Slovenskih goric so najbolj zgoščeni vinogradi. Dobri dve tretjini vinogradov je v razredu šibke erozije. Najbolj enakomerno so razporejeni travniki.

V izseku Haloz so najbolj zgoščeni sadovnjaki. Štiri petine jih leži v razredu šibke erozije. Najbolj enakomerno so razporejene njive.

V izseku Goričkega so presenetljivo najbolj zgoščeni travniki. Skoraj dve tretjini travnikov je v razredu šibke erozije. Najbolj enakomerno so razporejene njive.

Poleg razporeditve vrst rabe tal po erozijskih razredih je zanimiva tudi gostota posamezne vrste rabe tal v posameznih erozijskih razredih.

V izseku Goriških brd dosegajo največjo gostoto gozdovi v razredu močne erozije z gostoto 92 ha na km², v izseku Koprskih brd gozdovi v razredu močne erozije z gostoto celo 99 ha na $\mathrm{km}^{2}$, v izseku Brkinov gozdovi v erozijskem razredu močne erozije z gostoto prav tako 99 ha na $\mathrm{km}^{2}$, v izseku Haloz gozdovi v razredu močne erozije $z$ gostoto 88 ha na $\mathrm{km}^{2}$ in tudi v izseku Slovenskih goric gozdovi v razredu močne erozije z gostoto 69 ha na $\mathrm{km}^{2}$, v izseku Goričkega pa travniki v razredu močne erozije z gostoto kar 100 ha na $\mathrm{km}^{2}$.

To je tudi največja gostota travnikov v vseh izsekih. Njive imajo največjo gostoto v izseku Goričkega v razredu neznatne erozije z gostoto 41 ha na $\mathrm{km}^{2}$, vinogradi v izseku Goriških brd v razredu neznatne erozije $\mathrm{z}$ gostoto 40 ha na $\mathrm{km}^{2}$, sadovnjaki prav tako $\mathrm{v}$ izseku Goriških brd v razredu neznatne erozije z gostoto 13 ha na $\mathrm{km}^{2}$, gozdovi pa $\mathrm{v}$ izseku Brkinov v razredu močne erozije $\mathrm{z}$ gostoto 99 ha na $\mathrm{km}^{2}$

Gostota njiv je v vseh izsekih največja v razredu neznatne erozije in se zmanjšuje z rastjo erozije. V razredu močne erozije je v izseku Haloz gostota njiv manj kot 1 ha na $\mathrm{km}^{2}$, v ostalih izsekih pa njiv v tem razredu sploh ni. Gostota gozdov je v vseh izsekih najmanjša v razredu neznatne erozije in se povečuje $\mathrm{z}$ rastjo erozije. Gostota vinogradov in gostota sadovnjakov sta v vseh izsekih največji v razredu neznatne ali razredu šibke erozije. Gostota travnikov se glede na razrede erozije v splošnem najmanj spreminja. V izsekih Goriških brd, Koprskih brd in Brkinov se njihova gostota z rastjo erozije zmanjšuje, v izsekih Haloz, Slovenskih goric in Goričkega pa narašča ali ostaja približno enaka. To je opazna razlika med primorskimi in celinskimi izseki.

Zanimivo je tudi spreminjanje gostote posameznih razredov erozije po posameznih vrstah rabe tal. Gostota površin z neznatno erozijo je v vseh izsekih največja pri njivah, na primer v izseku Brkinov kar 67 ha na $\mathrm{km}^{2}$ njiv, najmanjša pa pri gozdovih, na primer v izseku Brkinov le 8 ha na $\mathrm{km}^{2}$ gozdov, razen pri izseku Goričkega, kjer je to pri travnikih.

Gostota površin s šibko erozijo je v vseh primorskih izsekih največja pri vinogradih, na primer v izseku Brkinov kar 87 ha na $\mathrm{km}^{2}$ vinogradov, v celinskih izsekih pa največja pri sadovnjakih, travnikih in gozdovih, na primer v izseku Haloz 80 ha na $\mathrm{km}^{2}$ sadovnjakov, v izseku Slovenskih goric 68 ha na $\mathrm{km}^{2}$ gozdov in v izseku Goričkega 64 ha na $\mathrm{km}^{2}$ travnikov.

Gostota površin z zmerno erozijo je v vseh izsekih največja pri gozdovih, razen v izseku Goričkega, kjer je največja pri travnikih, najmanjša pa pri njivah, razen v izseku Haloz, kjer je najmanjša pri vinogradih, in izseku Goričkega, kjer je najmanjša pri sadovnjakih. 
Gostota površin z močno erozijo je v vseh izsekih največja pri gozdovih, razen v izseku Goričkega, kjer je največja pri travnikih. Ker je v izseku Goričkega le $0,01 \%$ vseh površin v razredu močne erozije, je vsa dejstva, ki se nanašajo na ta razred, treba upoštevati z zadržkom.

Slika 33: Erozijska ogroženost območja v okolici Bočajev, Koprska brda.

Glej angleški del prispevka.

Slika 34: Erozijska ogroženost območja v okolici Pregarij, Brkini.

Glej angleški del prispevka.

Slika 35: Erozijska ogroženost območja v okolici Imenj, Goriška brda.

Glej angleški del prispevka.

Slika 36: Erozijska ogroženost območja v okolici Kočic, Haloze.

Glej angleški del prispevka.

Slika 37: Erozijska ogroženost območja v okolici Pršetincev, Slovenske gorice.

Glej angleški del prispevka.

Slika 38: Erozijska ogroženost območja v okolici Markovcev, Goričko.

Glej angleški del prispevka.

Legenda za slike 33 do 38: neznatna erozija - rumena, šibka erozija - oranžna, zmerna erozija - svetlo rdeča, močna erozija - temno rdeča.

\section{Sklep}

V izseku Goriških brd, Brkinov in Goričkega ni izrazitih zakonitosti spreminjanje deležev posameznih vrst rabe tal glede na rast nadmorske višine površja. V izseku Koprskih brd se z rastjo nadmorske višine v grobem manjša delež njiv in gozdov, rase delež sadovnjakov in travnikov ter ohranja delež vinogradov, v izseku Slovenskih goric pa manjša delež njiv in travnikov, rase delež vinogradov in sadovnjakov in travnikov, delež gozdov pa je največji v srednjih višinah. V izseku Haloz se le delež vinogradov jasno spreminja $\mathrm{z}$ nadmorsko višino, in sicer narašča $\mathrm{z}$ večanjem nadmorske višine.

$Z$ rastjo naklona se $\mathrm{v}$ vseh izsekih samo delež njiv izrazito manjša in delež gozdov izrazito veča, $\mathrm{z}$ rastjo ekspozicije od severnih leg proti južnim legam pa se v vseh izsekih manjša delež gozdov in veča delež vinogradov, razen v izseku Goriških brd, Brkinov in Slovenskih goric, kjer je delež vinogradov na južnih legah nekoliko manjši kot na vzhodnih in zahodnih, a vseeno bistveno večji kot na severnih.

$\mathrm{Z}$ rastjo potencialne erozijske ogroženosti v vseh izsekih rase delež gozdov in pada delež njiv, $\mathrm{v}$ sredozemskih gričevjih pa padajo tudi deleži vinogradov, sadovnjakov in travnikov.

V celinskih gričevjih so glavni indikatorji pomena reliefa njive, ki se vežejo na ugodne reliefne razmere, in gozdovi, ki se vežejo na slabe reliefne razmere, $v$ sredozemskih pa še vinogradi in sadovnjaki, ki se vežejo na dobre reliefne razmere. Razmerje med njivami, vinogradi in sadovnjaki na eni strani ter gozdovi na drugi strani je v izseku Goriških brd na območju neznatne potencialne erozijske ogroženosti približno $4: 1$, na območju močne potencialne erozijske ogroženosti pa $1: 15$. V izseku Koprskih brd sta isti razmerji $1: 1$ in $1: 860$, v izseku Brkinov $1: 3$ in $1: 503$, v izseku Haloz $1: 1$ in $1: 71$, v izseku Slovenskih goric $2: 1$ in $1: 6$, v izseku Goričkega pa $1: 1$ in $1: 4$ (v zadnjih dveh izsekih drugo razmerje velja za območje zmerne potencialne erozijske ogroženosti, ker na območju močne potencialne erozijske ogroženosti sploh ni njiv, vinogradov in sadovnjakov).

Korelacijski koeficienti kažejo, da je povezanost med rabo tal in potencialno erozijsko ogroženost pri sredozemskih gričevjih (Brkini 0,2420, Koprska brda 0,2336, Goriška brda 0,2227) večja kot pri celinskih (Slovenske gorice 0,2144, Haloze 0,1846, Goričko 0,1172).

V izseku Haloz je raba tal najbolj povezana z ekspozicijo površja in v izseku Slovenskih goric z nadmorsko višino površja, $v$ ostalih izsekih pa je najpomembnejša potencialna erozijska ogroženost. V izseku Slovenskih goric je na drugem mestu potencialna erozijska ogroženost površja, v vseh drugih izsekih pa naklon površja. 
Ovrednotenje koeficientov povezanosti med rabo tal in posameznimi reliefnimi kazalci na ravni Slovenije (Perko 1998; Perko 2001; Hrvatin in Perko 2003) je pokazalo, da je rabe tal najbolj povezana z nadmorsko višino površja, nato naklonom površja, manj pa z ekspozicijo površja. Pri sredozemskih in celinskih gričevjih s pomembnim deležem vinogradov pa sta naklon in ekspozicija površja pomembnejši od nadmorske višine površja. V splošnem je raba tal v sredozemskih gričevjih bolj prilagojena potencialni erozijski ogroženosti kot v celinskih gričevjih, vendar tudi v sredozemskih gričevjih še ni optimalna.

Pri vrednotenju izsledkov analize reliefnih kazalcev in vrst rabe tal je treba upoštevati stopnjo natančnosti DMV 12,5 (Podobnikar 2006) in zemljevida rabe tal (Dejanska raba ... 2005), ob tem pa se zavedati, da opisane značilnosti in zakonitosti zagotovo veljajo le za povezanost med izoblikovanostjo površja in rabo tal v izbranih izsekih.

\section{Viri in literatura}

Glej angleški del prispevka. 